УДК $821.16: 398$

https://doi.org/10.18485/godisnjak.2020.15.3

Немања Ј. Радуловић*

Универзитет у Београду

Филолошки факултет
Оригинални научни рад

Примљен: 15. 09. 2020.

Прихваћен: 10. 11. 2020.

\title{
ПРВО ЛИЦЕ И ДРУГИ СВЕТ
}

У раду се представља група текстова који нису били опажани као део једног корпуса, а који се узимају као пример посебног жанра: наратива у првом лицу о виђењу другог света приликом привремене смрти (под емским називом обмирание у руску фолклористику увели су га Н. и С. Толстој). Стабилност мотива и композиционе схеме оправдава издвајање ових наратива као примера посебног жанра. Испитују се везе са другим прозним жанровима, са веровањима, као и са писаном књижевношћу, на примеру црквених књига за народ. Такође се ови фолклорни есхатолошки меморати пореде са наративима о искуствима блиске смрти (NDE) који су стекли популарност у другој половини 20. века.

Кључне речи: искуство блиске смрти, меморат, есхатологија.

\section{Увод. Преглед истраживања}

Скуп текстова о ком ће овде бити речи невелик је. Пошто су ови записи углавном остајали ван хоризонта истраживача усмене књижевности, нису се ни опажали као делови једног могућег корпуса. Из истог разлога нису били ни жанровски прецизније одређени.

Реч је о наративима који описују, најчешће у првом лицу, стање привремене смрти, виђење другог света и повратак у живот. Један број записа је у трећем лицу, али се казивач позива на искуство неког блиског или барем познатог. Ова врста наратива добила је већу пажњу у руској

*nem_radulovic@yahoo.com 
фолклористици. Руских записа има још од 19. века, али тек је рад Никите и Светлане Толстој из 1979. (у овом раду се цитира према каснијем издању: Толстој 1995) увео овај жанр у фолклористику. Мада кратак и заснован на два примера, тај чланак је значајан због постављене тезе да је реч о посебном жанру. Као његове композиционе одлике наводе се: а) уводни део; б) основни текст и в) крај. Толстоји су одлучили да усвоје народни назив, тј. термин самих информатора, обмирание. Овај рад је подстакао друге руске фолклористе на бележење и проучавање, тако да се од деведесетих у тамошњој фолклористици обмирание учврстило као предмет проучавања дисциплине (нпр. Лурје, Тарабукина 1994; Толстој 1999; 2002; 2015; Добровољска 1999; Никитина 2002; Паунова 2002; Кринична 2004: 921-993; 2005; 2011). Прихваћено је мишљење да су записи манифестације једног жанра за који је усвојен поменути емски термин, a о функционисању тог назива и ван руске фолклористике сведочи што обмирание користе и англојезични проучаваоци (Вигзел 2003; 2005; Ловел 2003). Ипак, приметна је неодређеност која настаје када се пређе на етску категоризацију: говори се или о наративима или „расказима” (што би били кровни термини), или о легендама (Кринична). Оваква ситуација позива на прецизније жанровско одређење. Проучаваоци су с једне стране утврдили постојање жанра и жанровске особине. Тако Лурје и Тарабукина усвајају тезу о трочланој композицији, мада понешто модификовану: а) приказ ситуације умирања и оживљавања; б) приказ виђеног; в) како је доживљај утицао на даљи живот информатора. С друге стране су наративи послужили као основа за етнографску реконструкцију представа о оном свету. Неминовно се поставило питање односа хришћанских представа и оних других, које се често одређују и као претхришћанско наслеђе. Отуда је велика пажња посвећена и писаној традицији обмиранија, која

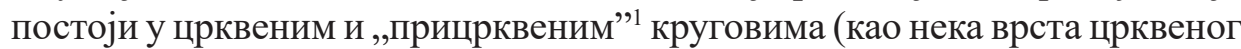
фолклора), и сродностима са средњовековним и још старијим наслеђем апокрифа, нарочито визионарских (жанр „виђења”) (в. нпр. Пигин 1996; Чередикова 2002). Уочена је и сродност са жанром „духовног стиха", коме би код нас, барем делом, одговарале легенде у стиху (Толстој 1995). ${ }^{2}$

\footnotetext{
${ }^{1}$ Сасвим услован и само за овај рад употребљен израз, према руском (уп. А. В. Тарабукина, Фольклор и культура прицерковного круга, докторска дисертација, аутореферат доступан на ruthenia.ru).

${ }^{2}$ Исто тако, управо поводом ових текстова, критикован је модел двоверја, који дуго доминира у руској фолклористици. Уместо њега се као истраживачки концепт предлаже синкретизам, као више нијансиран, а и зато што укључује историјску димензију религијских веровања, занемарену у семиотичким и типолошким приступима, који су по самој својој методологији склони аисторизму (Вигзел 2003; 2005; Ловел 2005). Делује, међутим, да је
} 
Двадесет година након првог рада о овој теми С. Толстој дала је пресек тренутних и могућих будућих истраживања, који је актуелан и данас, када нас од тог другог чланка дели додатних двадесет година. Након поновљене тезе о жанровској самосталности и трочланој структури, она упућује на поређења са писаном традицијом; са приповедањем о сновима; на проучавање питања генезе и географске распрострањености и на компаративна и типолошка изучавања (Толстој 1999).

Сродно томе, код других аутора издвојени су: а) жанр као извор народних представа о загробном свету; б) структура жанра; в) утицај других жанрова; г) поређења са писаним облицима (Грицевска, Пигин 1993: 49). Сафронов, који се посебно бави сновима, разликује три групе текстова о виђењу оностраног: приповедање о сновима, „обамирања” и „виђења” (Сафронов 2008). Он прихвата одвајање „обамирања” као посебне групе, различите од сна, али додаје и следећа запажања: структура и карактеристике које даје Толстој могу бити заједнички сновима и премирањима; структура се не мора цела јавити у сваком тексту; приповедање о самом догађају премирања може се јавити самостално, без казивања о оном што је виђено „тамо” (Сафронов 2016: 31-32).

У овом раду представићемо и истражити српске записе виђења о другом свету. Намеравамо да текстове представимо жанровски, са становишта фолклористике као проучавања усмене књижевности. Корпус који је предмет анализе чине текстови настајали од периода између два рата до данас; већи део је објављен, док неколицина долази из савремених теренских истраживања. ${ }^{3}$ Простор с ког записи долазе је веома широк: Шумадија, околина Београда, југ Србије, Босна, Црна Гора.

Како су неки слабије познати и расути по разним изворима, овде се доносе заједно.

\section{Текстови}

Стеван Дучић у Животу и обичајима племена Куча (1931) даје један запис који се позива на аутентични доживљај.

Један Премић однесен је да се сахрани па је над гробом оживео и казао, да је враћен с онога свијета. Он је, казују, причао, да је гледао ђе на оном свијету

ова критика усмерена пре на ширу употребу концепта двоверја, него на конкретне радове о „обамирању”, који узимају у обзир компаративну перспективу.

${ }^{3}$ Најсрдачније захваљујем колегиницама Лидији Делић, Смиљани Ђорђевић Белић, Јеленки Пандуревић, Данијели Поповић Николић, Ани Станковић и Светлани Ђирковић на љубазно уступљеним снимцима и транскриптима. 
хришћанске душе прима и на 'терезијама' мјери св. Арханђео, којему је с десна теразија арханђел Гаврил, а с лијева Али Каторис, цар ђаволски. И кад грешна душа дође, св. Арханђео је ставља на 'терезије', анђели с десне стране подижу теразије мачевима, да би душа изгледала лакша, а ђаволи с лијеве стране опиру мачевима у теразије, да би душа отегла, и онда ју воде у пакао. - У то вријеме дошла је душа једнога цара, и св. Арханђео га упита: 'Ко си ти?', а он рече: 'Био сам цар на земју'. Тада га св. Арханђео запита: 'Јеси ли право судио, гладнога наио, жеднога напио, голога одно (оденуо), препаденога ослободио, жалоснога овеселио, бонога понудио и сметенога поучио?' Па како царева душа на то није могла дати одговора, ставе ју на мјерило и ђаволи помогоше мачевима да теразије отегну, те цареву душу поведоше у пакао, и кад је баце у црну маст, зашрипташе зуби, вичући: 'охохо! охохо!' - Затијем дође пред светог Арханђела једна душица од ђетета близана, које је само један дан на земљи живило. И кад ту душицу св. Арханђео запита: 'Ко си?', она одговори: 'Нит имам вјере ни имена, е нијесам кршћена'. Но кад се и та мала душица ставила на теразије, нашла се нешто мало грешна, и даде јој се тежак и далеки пут преко једне танке длаке, која се није могла преодити до раја за 70 дана. Сјутрадан дође душица другога му брата, и кад га је св. Арханђео питао, има ли гријеха, рекла је душица: 'Ономадне сам рођена а данас умрла имам гријеха што сам плачући мајци досаду чињела и што је од мене имала теготу, што ме девет мјесеци под пас носила'. Ту душу која је и тако мален гријех признавала, нијесу на теразије метали, већ је уведу у рај (Дучић 1931: 303).

\section{Године 1939. Александар Петровић је у Гласнику Етнографског} музеја објавио више записа. Петровић даје народни термин („они који су обамирали"), који се подудара са руским. Ови су примери представљени првенствено као грађа вредна за народна веровања, па зато уз записе целовитих наратива Петровић даје и одломке или препричане информације које треба да илуструју ширу слику представа о другом свету. Такође нуди неку врсту мале класификације виђења оног света: извештај после привремене смрти (они који су обамирали); они који су у сну видели покојнике и они који су „заносили” (могуће је да под овим последњим мисли на транс)

2. Обамирао човек, кад се повратио он прича: „Идем све тако путем, с једне стране шума и с друге. Тице певају, дан леп право пролеће. Идем тако, идем, сретне ме свети Аранђел. - Куда ћеш? пита ме. - Идем путем, одговарам му ја. - Врати се, ти ниси за овај свет. - Кад ћу онда? питам га ja. - На благдан, кад се пеку млади јагањци, кад у твоме селу има највише весеља. Ја се вратим натраг. Ишао, ишао па се пробудио.” Кад је дошла преслава, цело село слави. Пеку се јагањци, младеж игра, дошли гости из суседних села. Тај исти човек позове своју снају и рекне јој: „Снајо, пошаљи у дућан за свећу и машину. Донеси корито, наспи топле воде да се окупам.” Пошто се окупао, обукао је ново одело, легао је на кревет, узео је фрулу и свирао је као што чобани свирају за стоком. У неко доба престаде свирати и рече: „Ево светог Аранђела, седи код мене, гледа ме”. 
Па продужи опет да свира. Кад би кроз једно пола сата он остави фрулу, запали свећу, прекрсти се, па прекрсти руке на груди и - умре. (Сланци)

3. Умирао је човек. Иде путем а тамо пуно људи. Неки седе па причају, неки тешу грађу, неки зидају кућу, поред једног великог дрвета игра коло. Света пуно као на вашару. Неки се напише, па се богме и побише. Дођоше жандари те их развадише. Сретне га наш покојни Миљко, општински писар. Носи испод руке нека акта. - Шта ћеш ти овде? пита га Миљко. - Незнам ни сам, ето дошао сам. - Е вала осрамотише ме, жали му се Миљко, ниси ти позват него твој комшија Марко. Враћај се одмах натраг, за тебе овде нема места. Пази добро, кад умре твој побратим ти ћеш одмах за њим. (Топола, Срез опленачки)

4. Занео се човек па се повратио. Питају га кога је видео. Он описује све своје сељаке које је познавао а који су умрли. Пита га мајка за сина који јој је умро у војсци: Виде ли мога Анатолија? - Видео сам га, пушку носи, стоји на путу: - Где ћеш? пита ме. - Идем тамо, одговарам му ја. Ниси ти за овде, врати се натраг. И ја се вратих. (Врчин, Срез грочански)

5. Заносио се човек па прича како отац држи на крилу мало дете, бере му цвеће, тура му у недра а оно му све пропада кроз недра, јер дете кад је сахрањено није било опасано. (Каменово, Срез млавски)

6. Кад човек премире прва жена стоји и зове га. Мој је отац тако премирао и јавила му се прва жена, звала га, а он све виче: „Росо, са' ћу”, „Росо, са’ ћу. (Железник, Срез врачарски)

7. Они који су обамирали па се повратили причају: „На ономе свету поређани су пуни столови, мртви седе поред њих, свет гледа на јело, али нити једе нити пије", јер се тамо и не једе и не пије. Пред њима стоји све што је подељено. Штогод се да мртвоме за душу или му се намени, све то стоји пред њим. Један је имао куче под столом. - Зашто ће ти куче? питам га ја. - Волео сам га док сам био у животу, пазио, па је оно сад дошло и чува мене. Остаје код стола кад некуд одем". (Зуце)

8. Један је човек заспао на гробљу и спавао 24 сата. Снио је да иде на суд. Обукао нову, чисту кошуљу, нове опанке, чакшире, гуњ и пошао је код најстаријег суда. Кад је дошао до капије а тамо стоји стражар и пита га шта тражи. Кад му је овај одговорио, стражар му нареди да се одмах врати кући, јер треба да иде код другог суда. Вратио се натраг. Враћао се, један стражар иде напред а један за њим. Наиђу на липсалог коња. Онај стражар што је ишао напред наређује му: забутај се у уста у ту мрцину. Сирома човек проба, проба али не иде. Како је силно главом ударио о мрцину избио јој је два зуба. Онда онај што је ишао напред удари коња по д... што је јаче могао. Кад је стражар ударио коња, човек се нама' пробуди 
и скочи с кревета. Осетио је како га боли место, по коме је стражар ударио мрцину. Пипне уста, кад тамо а оно два зуба фале. Он се онда сети да то није била коњска мрцина него његово тело. (Шетоње, Срез млавски) $)^{4}$ Петровић наводи и неколико снова и варијанту легенде о Св. Андреју као великом грешнику.

\section{9. Вајар Сретен Стојановић у својим успоменама доноси једно све-} дочанство које је чуо његов отац, свештеник.

Отац је причао, једне вечери када се вратио из парохије, како је неки сељак говорио да је био умро и да је дошао пред рајска врата, али да му свети Петар није дао да уђе. Он се чудио јер је био праведан. Отац је тврдио да је сељак један од најчеститијих људи у парохији. Сељак је приповедао како му је свети Петар наредио да погледа десно - тамо је угледао како гори један плот и стаја. Он се тада присетио да је то горело на имању његовог комшије, а он је био тај који га је упалио, још у младости, само је сада заборавио. Свети Петар му је рекао да се врати на земљу јер сада није време да умре већ на Светог Јована. Сећам се како је отац на Светог Јована са узбуђењем отишао у село, а када се вратио саопштио је да је то јутро умро тај домаћин (Стојановић 1997: 25).

\section{0. Слободан Зечевић у оквиру етнографске расправе о култу мртвих} препричава један наратив очигледно саопштен у првом лицу:

Треба напоменути да нису ретки случајеви вере да и жив човек може отићи на онај свет и вратити се натраг. Обично, када психопомпос доведе душу до брвна које премошћује пут у рај, судија у својој књизи сравњује податке које му душа даје о себи. Ако утврди да се подаци не слажу, он враћа душу на овај свет. Када се душа врати у тело, мртвац се буди и наставља са животом, а умире други човек истог имена, место кога је бивши покојник грешком позван на други свет. Прича се о случајевима да је могуће и да се преваром врати с другог света... Жена Н. П. из Кобишнице прича да је психопомпос када је дошао по њу морао да поведе на други свет и неку душу из суседног села. Пошто је била боса а пут нераван, она предложи психопомпосу да је не води са собом у друго село, већ да га сачека на раскрсници путева. Овај на то пристане и упути се по другу душу. Жена искористи тренутак, побегне натраг и сакрије се да је психопомпос више не нађе, те тако остане жива (Зечевић 1967: 48-49).

Ови се подаци односе на влашко говорно подручје. Исти податак Зечевић наводи и у Култу мртвих код Срба (1982: 26), где је психопомпос поменут, очигледно термином информаторке, као „чича”. Схема коју Зечевић наводи, изгледа на основу више причања које је чуо, сасвим одговара примерима које налазимо и другде.

\footnotetext{
${ }^{4}$ У овој варијанти није непосредно описано умирање, али је двадесетчетворочасовни сан на гробљу искуство довољно изузетно и блиско привременој смрти, као што је и сам наратив подударан са осталима из ове групе.
} 
11. У Расковнику је 1990. (бр. 61-62). објављен опширан запис у првом лицу. Језик овог записа је можда последица схватања да се говор информатора не сме мењати, али не искључујем ни могућност стилизовања - на крају крајева, Расковник је изворно био часопис намењен представљању писаца-сељака, а овај језик подсећа на облике прозе из седамдесетих, попут оне Душана Јагликина или Моме Димића. ${ }^{5}$ Због опширности дајем само сажетак.

Информатор Ђорђе Јовановић (Ђока Будић) саопштава како је у 28. години добио грозницу и потом прешао преко воде, у лађи, на неку ливаду. Ту је видео смрт и ђаволе који су му ишчупали душу, као грешнику. Појављује се његова слава, Велика Госпојина, окружена анђелима која се заузима за њега јер је поштовао празник. Анђели погледају књиге и проводе га кроз митарства, где се расправљају са ђаволима о Ђокиној грешности. У једном тренутку глас позива да га врате доле „ради хитне провере”. Испоставља се да су анђели узели погрешног Ђорђа Јовановића, а наратора враћају у тело, односно враћа се у живот. Сазнаје да је четири дана лежао „ни жив ни мртав”. Након тога се исповеда свештенику, који му објашњава да су његова виђења била митарства, а како се сад исповедио, по смрти неће морати да пролази кроз њих. Наратор саопштава да сад води рачуна о греху и да му је свеједно колико ће још да поживи. ${ }^{6}$

12. Збирка Драгољуба Златковића (2007) доноси један запис датиран на 1989.

Жена се тенчила, умрела. И дошли попове, опојали ђу. И она седне у ковчегат и попат си побегал. А она рекла: - Јелате да ви каем какво је на онија свет. Горе ми рекоше још годину че седиш доле, па че после дојдеш горе! Мајћа ми била кад се това десило. Черка девојка на туја бабу умрела, Кола. И бабичката рекла: - Кола и мојта черка ка пуштиле перчиње, од милине да ђи гледаш. А башта ми, колена му брашњива, сцепена, па ми каже бил сам воденичар, киво сам мерил, затова су ми таква колената, и кантарат ми на шију виси, а ћијьцат ме удара у колена! (Златковић 2007: 590, запис бр. 489; 1989, Таска Стојанов, 1907, Горњи Криводол).

\footnotetext{
${ }^{5}$ Индикативно је да је записивач, Златимир Пантић, иначе аутор једне збирке песама, неке од ових записа после 2000. поново објавио у часопису Омаја, посвећеном фантастичној књижевности, као и у збирци Тако је било, очију ми (укључујући и текст о Ђоки Будићу). Мада су свакако пожељнији транскрипти рађени по строгим узусима, ово не значи нужно да овакве публикације треба одбацити: суочавање с таквим текстовима је једноставно неминовни део истраживања усмене књижевности и протеже се и на старије записе.

${ }^{6}$ Записивач додаје коментар о смрти наратора и своје уверење да неће ићи на митарства.
} 


\section{3. Збирка приповедака и предања из Левча Снежане Марковић доноси један запис:}

А ово што сам ти причала, мој свекар исто и премирао, био мртав па се диг'о, био други разред у школу. То је истина било, кад је бо други разред у школу и он само заболи га глава и готово умро. Они га окупали и ставили га на сто и каже мој свекар овако: „Дете, чујем ја, кука нана, кука тетка, а ја тонем, каже, и идем. један дош'о човек са оволику браду и књигу у руке и мене каже: „Милутине, 'ајде с моном да пођеш!” Ја каже, не противим се и с њим пођем. И кад сам ја пош' о с њим, ја идем у дибину/!/, а чујем глас неки да кука, из дубине, и не чујем ништа. Прош’о сам прво кроз једну ливаду, трава. Друга је цвеће цветало, милина. Деца беру цвеће, неко које каже, није кад је умрло, па није повезало каиш, или канице некад иле зване, каница али већином децама каиши били везани, оно каже бере оно му испада, оно плаче. Туд' смо прошли па прођемо, кажем на другу месту води ме онај светац, ја за њим, прођосмо, каже на другу месту води ме онај светац, ја за њим, прођосмо на једну као шипка, овако као мост. Ту, каже, прођосмо, ја да се вратим, ал' не да он мене да се вратим. Он напред мене вуче за руку да идем даље у другу ливаду, преко тога моста. Сад ћу, ја, кажем, гле'м доле вода, сад ћу да паднем, ма идем ја, каже, к'о да широк овако мост, ако иде оно као шипка. Тамо смо прошли, каже, с једне стране, каже гледам бију се два човека. Ја питам оног свеца: „Шта, каже ови раде?” „Бију се браћа каже, за међу.” С друге стране гле’м, каже, жене се бију. „Шта је, каже, ово?” „Жене се свађу за прељубу.” Са друге стране прелазимо, каже, вода ври, казан час горе, час доле. „Шта је, каже, ово?” „То су, каже, грешници, ко је грешан он, каже, ври у тај казан!” Па смо прошли мало даље, кад тамо грану Сунце, о Боже ме прости, као злато, као Сунце оно кад сине, једна, каже, врата златна, отворише се та врата, пође, каже, светац напред, ја за њим. Кад тамо стоје, каже, свеци, све у круг. Ја сам стао. Нигде дете ту нема. Само матори, као свеци стари, и ја, каже, сад гледам, па ћутим, не смем ништа да говорим. А отуд се диже један светак велики, брада му ама до пупка и књигу највећу носи и каже онем свецу: „Па нисам ја тебе рек’о тог Милутина Милојевића да узмеш. Тога Милутина да вратиш, него с оне стране реке, Ђорђевић Милутина да узмеш.” Мој свекар каже: „Ништа ја не знам, дете сам, немам појма, а мен’ онај светац даде једну књигу велику: 'А ти, каже, мали сад за њим све 'де он прош'о ту да идеш за њим и ову књигу да узнеш под мишке. Држи је добро и да читаш кад отиднеш, да је читаш!' Ја, каже, стег'о ону књигу, онај светак, он напред, а ја за њим, и, каже, ја ти се пробудим погледам ти ја на сто лежим, преко мене, каже, и покров, све ме прекрили, ја устајем и вичем: 'Где ми је књига, где ми је књига?' Ја почнем да плачем а они: 'Јо Боже, Боже поклони ми га и Боже ми га не узимај кад си ми га дао и створио и ја сам га очувала што ми га узе! Фала ти Боже, кад ми га врати!' Фала, каже, мајко Господу и овем чике што ме водио. Е сад, каже, ја сам се вратио. Ја сам био у рај. Ал' сам прош'о све где су и грешници, где су и рајска врата и где су и најбољи и најгори, па сам се вратио и дали ми књигу. Где ми је књига? Рекли су ми да читам ту књигу?' 'Нема ти књига'!” А он где му ј књига, поче да кука, каже: „Добро, нема везе ће ти дамо ми другу књигу, да ти купимо! Не знамо, каже, нисмо ми тебе књигу видели!” „Добро, то значи мене заварали, каже, само да се вратим истим путем, али фала, каже, Господу, него нане знаш шта?” Каже: „Шта?” „Сад ће да умре са оне стране Милутин Ђорђевић, тетка Марин Деверичић.” Он се диг'о од стола, скочио, сео нормално на кревет, отворили прозор, 
изашла ми та баба - ја је нисам запамтила - и са оне стране закукају. Отиш'о тај Милутин Ђорђевић куј требао да умре” (Марковић 2004, бр. 119).

\section{4. Новији теренски рад у ком су учествовале Јеленка Пандуревић,} Лидија Делић и Ана Станковић донео је овај запис: ${ }^{7}$

Те године кад је жена моја умрла, четерест, хиљаду девесто осамдесет осме, оно, мало даље, пеко сам печенцу мало даље, там се пече, сам пеко печенцу. Испеко. И

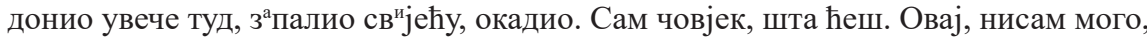
постио сам тај дан, рибе сам јео. Међутим, лего сам там на кревет. Шта је било с мене, ја не знам, само знам да сам у четр сата усто. Мени је сам знам, мени је дошла Света Петка и уфатла за руку и каре: „Ај са мном”. И она је мене водила према сад неђе там, као сад узмимо, откуд знам, водла, није далеко, као сад до дола. Прешо преко неке, ев волка клупа, даска. И она пређе, а дол вода. И сад одавле до градне, е ту ј вода. И сад, та дашчца, пређем, ништа немаш. И сад, тај знак, ако упанем доле, не могу там ђе она оће. Прешо ја. А оно ка сам прешо, оно мало даље, ко од она градина, сам плетена, један мој синовац, братов син, он је умро прије, тешки лопов био. Онога Гаге што опрема ту ове ауто, његов отац. У градни јауче. Дал је мене видио, дал је позно, јауче: „Дај, молим те, избави ме”. Ја га не би избавио, инако је тешки лопов био.

П: Да?

О: И окренем и ишо са том, овај, Светом Петком, сво док нисмо дошли на ваку ледину, там ми, вако трава, све почйшћено. Има неки вак мало неђе неки воћкица, кобајаг, има стазе, све стазе. Вако, вако, вако, све стазе и сједи ну двоје иксана, ну троје иксана, ну троје, ну четеро, ну четеро. Оном вак у правцу сједе моја браћа. Ал нико ништ не го ори. Њи видим, он ${ }^{\mathrm{n}}$ не го ${ }^{\mathrm{B}} о \mathrm{pe}$ мени ништ. Нисам ни ја мого нароч $^{\text {то } о ~ г о в о р ~}{ }^{и}$ т. Овај, кад ко нека, овак мало даље, пуно познајем жена, ал од комшија овд, ово-оно. И тако да, ну, има ту једно дијете, знам ја њега, знао и он мене, није далеко. Прије баш пар година, једињак у мајке и оца. Чуоㅜ кра ${ }^{\mathrm{B}}$, добар је ђак био, бијела коса му (нејасно 01.36.46-01.36.47), знам дијете. И он јадник сједио, чито, добро, ђе крава пасла, ту неће, а он чито. Крава се о нечег препала, тргла, одвукла га, пребије врат, погине дијете. И он мен оно даље није био код оне

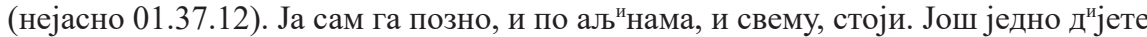
женско треба, одјећа шарена, дијете кике све има около и, овај, каже мени: „Ја сам

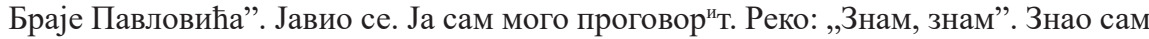
дијете, позно. То сам причо мајки, отац је умро ускоро.

Е, а остало. А остало, овај, одо там даље и Свете Петке је нестало. Онда сам ту одо и виђо те многе, тако да, овај... Но, наједанпута ми се нешто свидло, има нека ко терасца, да завирим у терасцу. Как сам завирио, врата отоворе $е$ на, погледо сам, кад оно моја соба, отвор ${ }^{\mathrm{e}}$ на врата (нејасно 01.38.20) сједи на кревету, окрено се там. Све нак како је умро, није реко рјечи. (нејасно 01.38.32) сједи он на кревету. Кад, пошо ја да изиђем отале, било све ко у терас ${ }^{\text {, }}$ сјећам се, још ко те плочице, откуд

${ }^{7}$ Информатор С. Р. (1927). Теренско истраживање било је организовано у оквиру пројекта „Проучавање и заштита нематеријалног културног насљеђа Републике Српске” (руководилац проф. Јеленка Пандуревић; финансира Министарство науке Републике Српске), а реализовано је у селу Батковић код Бијељине у априлу и јулу 2013. године. Део транскрипта који је овде под бројем 14. објављен је у: Делић 2015 (в. ниже), а разговор је вођен априла 2013. Запис који је овде под бр. 15. део је докторске дисертације А. Стаменковић (ментор Јеленка Пандуревић). 
ја тако видијо. Паде, паде, богте, и одупирем се на ову руку, усто б дигнт, ништ. Моја жена однекле долази, увати ме за руку, нако како је умрла, нако је мршава, бијели шико на њој био, ово-оно. И увати ме, повуче, вели: „Ниси ти још за овамо". То је рекла и друго није ништа рекла.

А што се тиче Исса Криста, неће Исус Кристос никад доћ, попов лажу. Вичу да ће доћ, попови , да ће доћ Ис ${ }^{y}$ с Кристос народу да помогне, да васкрсе, да овако, ${ }^{\circ}$ нако, радујте се. Ја сам лично био с Иссом Кристом и с његовом мајком, све. Неће доћ, реко је да неће. Ја сам реко оним поповма: „Што џабе лажете народ?” Нећ

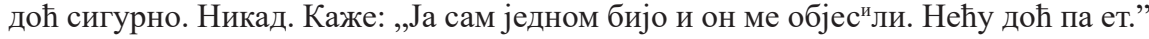
Није мртав, Исс Кристос, он је посвећен, али нормално да не иде, посвећен. Он је туд, а мало подиго се и там гледа. Глава му на тој страни 01.40.18). И то је све.

П: Значи, били сте тамо, на оном свијету?

О: Ет, кајем ти, био код Ис ${ }^{y}$ Ка Криста, био исто многи свијет. Тамо има свијета још, мислим, и тог зеленла и тога, ал не могу нисам мого ић, нисам мого (нејасно 01.40.42). А био сам, кажем т ${ }^{\text {}}$, ето поједини кажу, нема.

Видиш ти, један човјек овд, ево овд што реже, има резару у Батковићу Његов отац био Будо. За врјеме Титове, онај, чете рес осме, седме, биле оне обавезе,

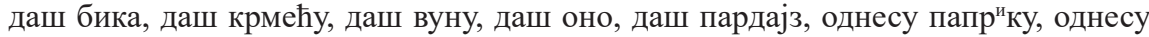
пасуљ. Сто кила, педесет, как ${ }^{\circ}$ ко море. Није давала нула ништа. Категорија нула, то ништа. Овај, и так, ово-оно, и све је то давато з в војску. Ја сам био с оцом, сјећам се, давал смо сигурно два бика и нешто крмака и нешто там-вам. Једног динара нисмо добили. Ал отприлике да је нешто и давато ти пара, ал мени. А тај Будмир, његов отац био пресједник и ка сам, и њега сам видио исто тамо. Ка сам там дошо идем ја (нејасно 01.42.00-01.42.01), он се држи за један труп с ову страну, а унук му и Драганов син с ону страну. „Шта радиш, Будмире”, ја питам.

П: Да?

O: Кае: „Ништа, ево гледам како људи раде”. Нит има људи да раде, нит ишта. Као, раде људи, њи нема. Каже мени: „Јеси дошо, Станко, по оне паре што сам ти дужан? Кажи мом сину Драгану”, као овоме, „нека т да он”. А није реко по оном Мићи, што је у Бјељни имо кућу, што ј био возач. Сад ја никако не мислим, ја нисам даво чојеку паре, ја никад нисам лаго. Мен је то и спасавало што нисам лаго. Никад. И, овај, него само тако он ј узео сам паре. Сам. Ет ја сад ов ${ }^{\circ}$ ме ммку не б мого каза т: „Дај ми толко и толко” да с срамотим, појма немам ништ. И тако то стоји. П: Значи, свашта сте тамо видјели, народа познатог?

O: Па нема од тога ништа, дуге приче. Кајем ја теби, видй јашта сам, овај, све људи што су радли овде већином и там раде, као шверцери. Не раде они. А и мој ујак био јаки шверцер с крмцима, говедма, овцама. Коме узме паре, даће сутра прес ${ }^{\mathrm{jy}}$ тра, не да ником. И тај мој рођак, његов син, он је имо рођаке, био двајес седмо годиште, умро је давно, има неки десе го година. Осотјћи су они. Нашо сам на њи, и мој ујак стоји пред говедма и овцама и питам га: „Шта радиш, ујаче?” „Ет, гледам како једу овце и говеда”, каже, „пред њима зелена шаргарепа”. Ниједна се не миче, ни једе, а он каже, једу. Значи, (нејасно 01.44.25) с марвом па опет тамо је. П: Ко је шта радио, значи, на овом свијету, исто ради и на оном.

O: Онај му брат, син, онуд мало даље, није био код не куће, исто вак гледа, он волио нешто крмака. И једна цурца са њим, мала цурца до петнест година. А то с ја сјећам, моја мајка имала сестру, умрла око четрнест, петнест година и то је она, Гина јој било име. Каже: „Ово је тетка Гина”. И то је дијете ваљда и са њим и, овај, он тобоже гони крмке. Ниш јок, ниђе се крмци не мичу. Он, каје, гони. Ја не знам, то су мало теже ствари. 


\section{5. Следећи запис потиче из теренског рада Ане Станковић: ${ }^{8}$}

А јел има људи који су премирали, то сам исто чула то, то... Овај, премирали, па да су се враћали и да су (причали шта су видели) тамо?

$\mathrm{CГ}$ : (Е, сад ћу ти то испричам.) (објашњење о којој жени прича, лична имена). И ... премирала. И отишла сам код ту моју снају сас ту моју јетрву да шијемо нешто и моја снаја каже мени, она ме звала сејка: „Сејка”, каже, „дошла Славка”. Реко: „Где дошла?”... Каже: „Код Гину”. „Па”, реко, ,јел она премирала”, реко, „и дошла код њу?”. „Па да.” Она каже: „Ајде да је свратимо”, каже, „да је питамо”, каже, овај,= ИС: Аха.

СГ: = „како”, каже, „било и шта”. Каже: „Ајде”. Сврате оне, свратимо ми. Она: „Јо, прија Милена, здраво, здраво”. То и са Гину као и са овом Даном. И ја реко: „Славка, ајде да ми испричаш”, реко, „шта си”, реко, овај ... „видела”, реко, „кад си премирала"...

„Па, ништа”, каже, „прија Милена, ја”, каже, „спавам”, каже, „као спавала сам, и један човек долази”, каже, ,ја и не знам ни као кад сам ни пошла ни шта ни ништа. Само каже: Ајде ти, Славка, спреми се (кашаљ) и да пођеш сас мене. Па, где”, каже, „да идем?” (кашаљ) Па де ће д ијеш да ће д ијеш, каже, ја ћу да те водим де ће д ијеш. И ја се спремим,” каже... „и пођемо ја и он”, каже (кашаљ), „и пођемо ми”, каже, „иди, иди, иди”, каже, „и дођомо на један, река једна”, каже. „Она дубока”, каже, „немој да питаш колико”, каже. „А брв”, каже, (кашаљ) како ми она рекла тако како турила руку, е, толико колико моја рука широк брв. „Немаш за шта да се држиш”, каже, „нити уско, нити смеш да идеш. И ја кажем њему”, каже... „А он каже: Ајд, улази ту да пређемо преко тај брв. А ја”, каже, „кад погледам дол не види се ни дно од реку само видиш мало вода дол. Где”, каже, „бре да прођем? Па ту, каже. Па, ја," каже, „нисам полудела д ијем да паднем у воду и нећу никад ни д изиђем из ову рупу. Он,” каже, „отпозади увати ме за ту руку и за ову и каже: Само гледај напред, каже, $u$, и гази слободно, каже, ja ћу да те држим. И ја”, каже, „прођомо ми преко ту реку”, каже... „Прија Милена”, каже,” кад смо прошли тамо”, каже, „оно”, каже... ,ја нисам видела више децу”, каже, „у један луг", каже. Оно као ови лугови.

ИС: Аха.

СГ: „Трава ова”, каже, „жута рада и бела цветале”, каже, „то се само жути и шарени, а они беру они цветићи, праве венчићи, па стављају”, каже, „на главу. А вране”, каже, „оно док сам жива, ја има да памтим. То сам учинило”, каже: „Гааа, гаaа, гаaа!" Каже не чујеш ништа. „А там подаље се види”, каже, ,једна кућа. И он: Аjде, ајде, овамо ћемо код ону кућу. Отиднемо ми”, каже,” у ту кућу, он претрча пред мене, отвори врата”, каже. „Ја”, каже, „погледа: један човек седи, каже, уз астал и нешто гледа”, каже, „у једну књигу”, каже. „И овај му каже: Ево”, каже, „довео сам Славку. Он не подиже главу, нешто као пише. И он јопет каже: Довео caм, каже, Славку, по други пут. Не каже ни господаре, ни ово, ни оно. А онај човек каже: Па што си, каже, њу довео? Па сам ти реко... Е, то нисам”, каже, „сам запамтила коју Славку и одакле. Врћи jy, каже, брзо, док није касно. Он”, каже, „мене увати за ово, окрете ме: Силази, каже. Низ степенице исто, каже ово. И сиђем ја дол. Кад сам ја”, каже, овај, „пошла да као идемо одакле смо дошли: $\mathrm{He}$, не там, овам, каже. Оно једна велика ливада”, каже, ,а на ту ливаду”, каже, ,,једна кобила", каже, „пасе, коњ”, каже, „дал кобил-, коњ, не знам шта је, не знам. Пасе”,

${ }^{8}$ Информаторка М. М. (1931), разговор вођен у Новом Ланишту октобра 2014. Транскрипт А. Станковић. 
каже, „и ми право према онога коња”, каже, „идемо. Кад смо стигли”, каже, „код онога коња, кад је он прија Милена, зинуо”, каже, „оволика уста. Аjде, каже, улази mу. Где, бре, да уиђем? Каже: Ту, у тога коња.” Каже: „Па нисам шамава да ме поје коњ,” каже, „ћу ту да уићем. Он”, каже, „, једну руку ме узе под... бутине, а сас другу”, каже, „испод плећке и наби ме”, каже, „у онем коњу уста”, каже. „Кад сам се ја разборавила”, каже, „они ме и окупали и обукли и сандук направен”, каже, „све сређено”.

А мо јетрва пита: „Па где ти је тај сандук сад?” Каже: „Ене га на шупу”, каже, „там стоји”. „Па што га...”, каже, ,ја би га ицепала”, каже, „да га изгориш”. „Па што да га горим?”, каже. „Шта знам колко ћу да живим, нека га”, каже.

ИС: (смех)

СГ: И, каже, врати се она, и, и, каже, али живела шест месеца по то и после умрела после.

ИС: Аха, аха, аха.

СГ: И то испричала. ${ }^{9}$

Специфичну позицију имају записи које је у популарној журналистичкој књижици Србија пред вратима видовњака (1992) објавио Тома Тодоровић. Наравно, реч није о фолклористичким записима, али како је реч о истом сижеу, наводимо их овде. Питање аутентичности не треба да засени другу важну чињеницу: овакви текстови сведоче о значају тема за неку публику и о њиховом трајању између фолклорне традиције и популарних штампаних верзија, тако да би се могли убројати и у постфолклор.

16. Једно сведочанство говори о томе како је Мијалко Данов, дактилограф у Савезу слепих, постао видовит.

Године 1979. Мијалко преживљава клиничку смрт и постаје видовит.

- Када сам премирао, водила су ме два мушкарца. Срели смо човека беле браде и жену у црнини. Човек је ћутао, а та жена рече: 'Зашто њега водите? Вратите њега, а Милана доведите.'

- Ти да се вратиш и помажеш народу.

- Како да помажем? - упитах жену у црнини.

- Све ће ти се приказивати. Долазиће код тебе много људи, и ти ћеш ићи свуда по свету да им помажеш.

- Када сам поново оживео, истог дана умро је мој комшија Милан. (Тодоровић 1992: 9)

17. У другом тексту наратор по имену Сретен тешко се разболи и пада у привидну смрт. Након што се пробудио „из дубоког сна” приповеда:

Дођоше Павле и Филип [юегови покојни другови] код мене и кажу: „Хајде крени са нама.” Они напред а ја за њима. Идемо доле према Морави, путићем између њива, када стигосмо до оне провалије, лево и десно велика вода. Путић води право на једно уско брвно преко кога морамо

${ }^{9}$ Бјелица, разговор водила А. Станковић (исто у: Станковић 2020: 175-177). Транскрипт Ана Станковић. 
да пређемо. Иза мене лаје неки пас, па се плашим да ме не уједе. Велим њима двојици да ја пређем испред њих. Они ми кажу: „Није то пас, то ти мајка кука за тобом.” Кад стигосмо до оног брвна, на ивици провалије седи један стар човек у белој бради. Држи штап у руци. Павле и Филип прођоше, а кад ја наиђох, он стави штап испред мене и рече: „Где ћеш ти?” Велим идем с њима. „Не може! Врати се!” Окрете се према њима и каже да врате мене, а Зорана да доведу.”

Даље аутор књиге саопштава како је на месту виђеном извештају настрадао информаторов брат од стрица Зоран (Тодоровић 1992: 58-59).

Како видимо, чак и ако су пастиш, ови текстови следе структуру традиционалних.

18. Да проблем није нов, показује текст „Шта је видела баба Томанија на ономе свету”, с индикативним поднасловом, „из народа за народ”, који је Радован Јовановић објавио 1928. у сарајевском календару Просвета (166-167). Уводна фуснота даје контекст који нам је већ познат:

Негде поодавно, у Подрињу, десило се, да је у тежачкој задрузи Јовановића умрла старија жена, заправо замрла је била. Кад су је, на поњави, спустили крај гроба, жена се пробуди. Народ се препадне и побегне, али баба некако добауља у село, прездрави и умре тек после шест година. За то време доходио јој је тежачки свет са свих страна, да је види и да чује, како је било на ономе свету. И причала је баба Томанија, неуморно причала и сејала добро семе низ заостало Подриње. И заслужила је да се њена казивања, грађена на јакој моралној основи, забележе, а уз њих да се и она помене, од свог праунука, као онај сејач добри из речи Христових.

Сам текст гласи:

...Отад пођемо даље. Тета напр'јед, а ја у стопу за њом. Не би мало, па дођосмо до једне чесме. Л'јепа чесма, сва од камена, а вода шика дебело к'о ова моја рука и отиче једним поточићем. Мало на ниже угледам двије вашке. Реже једна на другу и 'оће да се изједу зубима, али им онај поток брани да се састану.

„Тето, јадна, да их развадимо”, велим ја, а она ће мени:

„Не виде добро твоје смртне очи. Нису 'но, д’јете моје, никакве вашке. Оно су ти чоек и жена. Живјели су рђаво на оном вашем св’јету, тукли се и свађали, па их Бог на овоме претворио у вашке и проклео, да се вјечно тако кољу... Него, кад се вратиш онамо, реци, по Богу, оној млађарији, шта си овђе виђела. Ако је то не опамети, не знам шта ће..."

Отален пређемо поток и стигнемо на једну велику ливаду. Ту нађемо много ђеце. Једна се играју, једна опет беру цвјеће и слажу у ките, да њима своја миле мајке с овог свјета дочекају. Ко ђеца! Немају грија, па им Бог и дао свако добро... Кад бисмо на по ливаде, а оно пред нама пањ, голем и огорио, а ервајн иксан. 
„Тето болан”, питам, „какав вам је то так’ и пањ!”

Не виде добро твоје смртне очи - каже она мени. - Ниј то пањ, већ жена нероткиња. Није да није могла од Бога, него није шћела од силе. Свашта је, веле, проклетица, радила да јој бреме струк њен не поквари. Док ти драгом Богу не додија и не спржи је гром, лицем на Огњену Марију. И, видиш је сад, у овој зелени и милини, она ко црни пањ, без икога свога, гледа туђу ђецу, кад већ своју није шћела да има... него, велим ти опет, дјете моје, кад се вратиш на онај твој с е н т, кажи свакој други, шта си овђе виђела...

Уто и ручаница....

Посједа онај народ по ливади, а из земље стадоше ницати софре. Пред сваким једна синија. Не видиш, ко их служи јелом тек пред сваким га има. Само, шта ми би чудно, нема пред сваким једнако. А виђох и то, пред једном женом само главица зелена купуса и на њој, да 'простите, псећа нечист. Питам тету а она ме повуче за рукав, па кад одмакосмо вели:

„Кад је она жена била тамо на вашем свјету, дошла јој Циганка и заискала главицу купуса, да скува ђеци. А она хајд, хајд по градини, док не нађе најмању главицу, а на њој се још и псето испоганило било. Одреза је и даде Циганки. То јој је било све што је у животу другом покучила, па и то без срца... Ето синко и то си виђела, па реци тамо, каки је 'вамо ред. Што ко од живих свом ближњем пружи, то му се само на овом свјету у вјечну његову 'рану пише..." (Просвета: 1928, 166-167).

Н. Милошевић Ђорђевић дефинише овај текст као прозну варијанту легендарних песама са сижеом посете паклу и оцењује га: „Директно под утицајем апокрифа [...] стилизована и доста опширна приповетка, у пригодно-наравоучителном тону 'за народ' [...] Иако садржи и народне мотиве песама о Огњеној Марији у паклу, не може се прихватити као народна" (Милошевић Ђорђевић 1971: 210). И стил и календарски контекст показују природу „штива за народ”, као феномена између усменог и писаног, односно фолклорног и књижевног.

Напомена приређивача је заправо познати нам оквирни део жанра, присутан је и лик водича (познатог покојника), али остатак је подређен каталогу грехова. На почетку је саопштено да је боравак путнице привремен.

У току израде овог рада добио сам неколико новијих теренских записа Смиљане Ђорђевић Белић из места Јеловац, Рибаре и Васиљ, која прилажем под бројевима 19, 20 и 21.

19. И: Да вас питам, а ел сте сањали некад старца (мужа) од како умро?

С: Па то нисам ја, скоро сам га ја шњела, код овце, све овце, реко, море де чува овце, шта ће ни те овце и на она свет! Каже, шта си радио на овамо, тако се ради и тамо, тако причу... Има куј видо. Мој свекар био премиро, па видо. Видо како то. Па, то се напио, па премиро, није онако да умре.

И: Па шта видо? 
C: Па видо ди прошо преко неко брвче (брвно), прође, прошо, каже, ту. А кад отишо там, није његов ред, врнули га. То видо. Тако прича, шта ја знам. Ја нисам видла ништа, а шњевам, скоро сам га шњевала ту, то је тамо. ${ }^{10}$

20. С1: А мој деда, мој рођени деда, ја сам велика била кад умрео, удала сам се, овде сам била. Овај, и он био болесан, беше болесан, и ће, био у болницу и ће да умре, шлогирао био и био болесан. И болује, ми се надамо да умре. Кад једно јутро се пробудио и виче мојем оцу: - Нећу, каже, ја да умрем. - Одакле знаш да неће? - Тако, каже, сањао сам, каже, ноћас. - Како си сањао? - Па сањам, каже, неки дошо сас браду велику, оволику, каже, браду носи. И повео ме, каже, негде, и води ме, каже, негде, и води, води, и идомо, каже, идомо. Кад неки отуда питују: - А де ћеш, каже, тога човека? - Па, тамо, каже, код вас. - Па није тај, каже, него Станимир, овај Јасков то био Станимир, горе. - Смо ти рекли ми за Станимира, каже, није за Миодрага. - А тај Станимир био Јасков. И мој деда кад се пробудио, тај га вратио. - Мануо ме, каже, и некте да ме води. - И мој деда виче сутра:-Сад ће, каже, Станимир да умре. - Одакле знаш? - Па сањао сам, каже, реко ми: - Онај ће да каже, ниси требао, каже, тога да доведеш него Станимира. - Кад други дан, умрео Станимир, чујемо. То је стварно било. Умрео Станимир. - Ел сам реко ја, каже. И он води ме човек, води, и врати ме. Де ћеш, каже, тога овам. - Погрешили. И после се диго мој деда, живео коџа по то. ${ }^{11}$

Један информатор (1972) из Васиља у интервјуу открива слику света која је занимљив пример бриколажа у ком се спајају народна религија и њу ејџ - појаву можемо назвати фолклорним њу ејџом. Донедавно се бавио алтернативном медицином и показује тематску и терминолошку упознатост с таквом литературом. Међу мноштвом тема, он је опширно говорио и о премирању, што дајем препричано.

21. У раном узрасту до 14 година био је атеиста, али му је једном на сан дошао Св. Јован Крститељ и повео га на онај свет. Све је било осветљено као по дану, флуоресцентним светлом. Видео је своје тело у постељи. Успео се уз четрдесет кристалних степеника; на сваком је један анђео и ђаво који говоре добра, односно лоша дела (отуда 40 дана у посмртним обредима). У великој белој просторији, за белим мермерним столом седе 24 старешине с белим брадама и у белим хаљинама (што је касније нашао у Библији). Пред њима је златна књига - књига живота где је записана свачија судбина. Када се отвори, књига је била бела, али се текст исписује сам где види своје име и датум. Старешине саопштавају Јовану Крститељу да информатору још није место овде. Показан му је пакао (на левој страни): врућина, смрад, длакави ђаволи. Пакао има

${ }^{10}$ Јеловац 5 С . Саговорница рођена 1936; разговор вођен јула 2017. Транскрипт: С. Ђорђевић Белић. Снимци се чувају у Дигиталном архиву Балканолошког института САНУ.

${ }^{11}$ Рибаре 1 СЂ. Саговорник рођен 1930; разговор вођен фебруара 2019. Транскрипт: С. Ђорђевић Белић. 
седам „нивоа” с градираним мукама. Наглашава да и свештеници свих вера, патријарси и папе исто иду у пакао - тамо их је видео. На седмом нивоу је сатана, у правом облику (леп, ,атлетски грађен”, црна дуга коса). Разговарао је петнаестак минута с њим, одбио је сатанине понуде, што је овог „изнервирало”. Враћају се код старешина па продужавају за рај. Леп мирис, као цвеће („који 'шанел пет”'). На капији (огромна, златна) стоје два анђела у белим хаљинама, који не желе да пусте информатора, јер душа још није чиста, али Св. Јован саопштава да има сагласност од старешина. У рају теку (као) кристалне реке, чују се хорови, играју деца, животиње које су заједно на ливади. Рај има седам нивоа. После шест стижу до дворца који је као од злата и драгог камења, не може се премерити. На вратима венац од пламена: то су херувими који чувају улаз. Једна соба је цео дворац. Унутра је пуно „народа”, тела им светлуцају, као да имају ореоле око целог тела (има и црнаца и „жутих”, „није рај само за православце и католике"). На крају хола велика светлост, сија јаче него сунце. То је Бог. Долазе до њега, клекну, љубе земљу. Види босе ноге, апостоле, ноге с ранама. Тад није знао да је то Христ. Христ га упућује да се врати на „планету Земљу”, а „домаћи задатак” му је да каже да постоје пакао и рај; добијаће наређења у сновима и да помаже народу; колико ко прихвати, толико да помаже. Пошто се већ „ослободио”, изражава жељу да остане на небу. Враћа се - поред њега родитељи, лекар пише смртовницу. Св. Јован га гурне назад у тело, по повратку у тело осећај изузетне хладноће. Лекар га упућује на прегледе. ${ }^{12}$

22. Други информатор из истог интервјуа:

СЂБ: А и ви сте рекли да сте имали клиничку смрт?

- Пао сам с дрвета са метра висину, и овај, и шта, пружа ми човек са брадом златну кутију, овакву, четвртаста, и даје ми, и ја сад, м, златна - (други информатор: јеси га и ти видео?) и мајка ту била поред мене и она виче, галами, озелене се, њише ce, њише, отац ми даје вештачко дисање, ја ни овамо ни онамо, онај пружа кутију, овам мајка кука, а ја не могу да проговорим, не могу ништа, док сам добио ваздух и после и ја се вратим код мајку, добро, добро, у реду, ништа ми није, а онај ми стварно тамо код онај свет пружа... неки брадоња. ${ }^{13}$ (Ђорђевић Белић)

Неки примери из већ наведеног теренског рада с пројекта о нематеријалном наслеђу Републике Српске постали су приступачни довршењем тезе једне од учесница.

\footnotetext{
${ }^{12}$ Васиљ 4 СЂ; саговорник рођен 1972; разговор вођен јула 2016.

${ }^{13}$ Васиљ 4 СЂ, 2016; саговорник рођен 1950. Разговор вођем јула 2016. Транскрипт: Н. Радуловић.
} 
23. Моја мајка била у кому, па ми причала. Она била у кому... десет сати... [...] Она премирала. И после кад се пробудила и после кад прошло дуго време и ја питам: „Мајко, бре, како ти било, шта ти било?” „Па”, каже, ,једни ме примају, други ме не примају и отворише ми се једна врата и каже: „Ти ни-, ти одлази назад, ти ниси за овам. И вратише ме”, каже. И ја с-, то ми мајка причала. „И вратише ме”, каже, „и ја отидо и пробуди се”. И она, ја знам кад се пробудила, она кукала: „Ијао, ијао." Муке имала. И скупио се народ био, сахрану смо спремали. И упалили ју свећу и... (Станковић 2020: 143).

24. СГ: Мој свекар премирао, он ш, шњевао.

ИС: Шта?

СГ: Каже да га водили. До, до школу га водили. То ни причао.

ИС: Аха.

СГ: Да га водио, дошо човек сас браду велику, и да га водио до, до школу. Кад је код школу дошо, оно га, каже... дал га причекао човек други. Каже: „Није то тај Блажа, други Блажа.” Оно после то, тај дан, он снио, преко ноћ. Ујутро један човек отера да, да коси, да рани краве, и заболи га стомак и док га донесу код куће, тај, тај дан, у 12 сати нешто га одведу код лекара, с коња га возили... И изврше перацију у три сата и он, ваљда, умрео, тај други Блажа” (Станковић 2020: 177).

25. ИС: Интересује ме, што се тиче раја, како, како људи описују, како су видели они што су премирали?

СГ (примери из породице): Ја... испред него што сам пала, поломила вилицу, ја сам сањала. Идем... лепота... са све брежуљци, трава зелена, јабуке, лепота. И све ... ниске клупе с једне стране и с друге седе. Прво седе старци, па после, да ти кажем, млађи и само шетање, шетање, и наилазим на човека све у црно, иде с једну жену и она у црно. „Враћајте ту”, каже, „жену назад. Она није још за овамо.” Одједампут се отворила једна глава и гурају ми моју главу, гурају да прође. Оно не може, не може, и одједанпут јако се отвори глава и ја уздахнух и рипи и разбудила сам се. То сам доживела у живот (Станковић 2020: 177).

\section{6. Преноси се и виђење другог света, на ком информаторка види и покојну унуку.}

Моја мајка видела цвеће и све, лепоту. Не прича ништа од јело... Али шта је упамтила... умре мојем брату и снае, умре и дете прво дете, девојчица, умре од четири дана, некршћено, само молитву ишла да му, и ту га одма саранила. То се тако каже. Тунај посади неко дрво родно, вишња, трешња, трешња мислим да има...туна. И она... и моја мајка каже: „Видела сам оно (...) дете, порасла девојчица." И ја сам је запитала то, то вече и ујутру и док сам пошла у дванаес сати са сестру заједно, ја је питам како, она: „Црвене машнице”, каже, „а хаљиница бела, па... црвене, са тачкице...” И лепо каже тачкице. И све то причала, свесна била (Станковић 2020: 173).

Постоји и сведочанство виђења покојних сродника у тренутку умирања.

27. А отац кад ми умирао, то ми брат причао, ја нисам била ту кад ми отац умирао, он пружио прст и казао: „Видиш овога човека”. Каже: „Видим”. Каже: „Е, тај 
човек дошао да нас раздвоји, тај ће не човек раздвоји.” И после пола сат умро... То ми је брат причао (Станковић 2020: 142).

28. Ја верујем да има нешто. Верујем да има нешто. А знаш како верујем? Била сам присутна кад ми умрела мајка, кад ми умро муж и била сам присутна брат кад ми умрео. И брат ми каже, знаш шта ми реко брат? Е, то ме највише болело. Ја уватим за руку и кажем: „Брате, јел знаш ко ти дошо?” (дигресија како је дошла). Каже: „Кој? Реко: „Сестра.” А он каже: А, па, ја сад имам две сестре.” А знаш да ни један сестра умрела (Станковић 2020: 142).

Поменућемо и два примера правих предсмртних визија, оба из градске, образоване средине.

29. На сахрани Момчила Настасијевића књижевник Милутин Деврња одржао је говор у ком је рекао: „Када је умирао, Момчило Настасијевић је имао визију коју је присутнима, сестри и брату, казивао својом незаборавном вештином: видим бескрајна зелена поља и несагледљиве цветне ливаде" (Деврња 1938).

Замисао оног света као поља одговара традиционалним представама. Извештај о песниковој смрти касније су понављали чланови породице и поштоваоци (Владета Јеротић, Зоран Глушчевић), тако да је на неки начин наратив заживео у преношењу, па и у стварању култа.

30. Математичар и антропозоф Милош Радојчић, који је иначе бележио своје снове које је сматрао видовитим, оставио је један запис назван „Саопштење моје маме 5.3.1948”:

Имала сам дивно привиђење. Тебе, је ли, занима шта се види кад се умире? Видим дивну терасу, сунцем обасјану, пуно цвећа, највише бело. Моја мама носи пуно цвећа [нечитко] Ја њу гледам, она мене и смеши се, и тако у недоглед. Онда је цвеће постало румено. Ја стојим нешто ниже (?) од Маме. Гледам моје [нечитко] сунцем обасјано. Је ли да је дивно? Све ћу ти причати. ${ }^{14}$

Како видимо из материјала, Радојчићева мајка преминула је марта 1948. Немамо целовит наратив, већ, као и код Настасијевића, једну слику. Задржана су два традиционална мотива: сусрет с покојним сродником и цвеће, само овде премештено у други простор (тераса). ${ }^{15}$

Неколико етнографских студија је поменуло појаву „премирања” без давања записа. Драгутин Ђорђевић у свом опширном опису живота и обичаја у Лесковачкој Морави помиње: „Дешавало се да неко привидно умре а после се пробуди. То је 'премирање'. Такви самртници, кад се

\footnotetext{
${ }^{14}$ Копије грађе Милоша Радојчића чувају се у Архиви Математичког института САНУ. Захваљујем др Милошу Миловановићу и другим запосленима у Институту који су ми омогућили приступ грађи.

${ }^{15}$ Која се јавља и у примеру бр. 14.
} 
освесте, причају све шта су видели на оном свету и та казивања се дуго препричавају, и преувеличавају.” (Ђорђевић 1958: 489-490). Међутим, не даје никакав запис. Александра Павићевић у студији заснованој на теренском раду истраживања смрти говори о сновима које пореди са „искуствима блиске смрти”: „Снови који у случају нашег материјала подсећају на овај феномен обично имају устаљену структуру: онај који сања, грешком бива позван у смрт и након виђења другог света, враћа се у живот. Ове представе још увек подсећају на виђења раних хришћанских мученика записана у њиховим житијима, мада се, често осим човека $c a$ брадом и човека у белом, као водич кроз онај свет појављује неко од познатих покојника" (Павићевић 2011: 225). Очигледно је да композиција одговара наративима какве разматрамо. (Ауторка је испитивала и сеоско и градско становништво, а овај пример се односи на грађу са села). Анамарија Сореску Маринковић наводи саопштење, као део „шире дискусије о митским бићима код Влаха", које на нивоу неколико мотива има сличности с наративима које разматрамо. Особи на самрти долазе три женске особе (суђенице), као и неко од породице ко је недавно преминуо; након што му Св. Аранђел извади душу, покојник угледа самодиву („Она није демон смрти, она је смрт сама”): „она чека после на оном свету, да стигне тамо, значи писарица, и она чека и запише га на каменој столици [...]” (Сореску Маринковић 2009: 263-264). Мада рудиментарно, и ово сведочанство наговештава посмртни пут, сусрет са психопомпосом и судијом, али су овде саопштени као опште правило, не као лични наратив, пошто није реч о „премирању”. ${ }^{16}$

Мада ова тема није привукла пажњу писаца као неке друге из усмене традиције, ипак постоји и њена књижевна обрада. Приповетка „Реч о животу оца Тодора овога и онога света", из збирке Из тамног вилајета Момчила Настасијевића садржи и обраду наратива о премирању. Марко звани Смрт, „ком је двапут воштаница паљена више главе”, описује у првом лицу како је стигао до капије неба - као сунце „боје љубичице” заједно са свештеником Тодором, за ког је врло неизвесно да ће тамо ући. Марка „нешто повуче натраг силно” и с том неизвесношћу враћа се на овај свет. Марко помиње лепоту оног света, природу, на начин који претходи ономе што ће, према Деврњи, саопштити сам Настасијевић. ${ }^{17}$ Искуство

${ }^{16}$ Посебан је проблем што је, како ауторка каже, реч о „секундарној нарацији”, насталој да објасни другу појаву на терену, а треба додати и да је информатор и сам етнограф истраживач, Паун Ес Дурлић, што у саопштење уводи један метаелемент.

17 „И онда пуче равница зелена травом, нити нога по њој утаба путање, да те милота обузимаше погледати, а туга загазити. И поветарци тецијаху туда мирисно. Па мили оче, 
привремене смрти и извештај повратника у основи су и Сабирног центра Душана Ковачевића, али је онај свет уклопљен у ширу, црнохуморну слику света и далеко сложеније односе живих и мртвих.

Што се истраживања у домаћој науци тиче, док је српска етнографија континуирано пружала студије о смрти, дескриптивног и, нешто мање, интерпретативног карактера, и док је посветила пажњу измењеним стањима свести попут транса, привремена смрт и виђења током ње остали су суштински непроучени. Видели смо како су Петровић и Зечевић користили овај жанр за реконструкције представа о другом свету. Светлана Толстој се у систематизацији мотива такође позивала на записе А. Петровића. Када је реч о фолклористици, тек је новији рад Лидије Делић издвојио категорију наратива о посети оном свету, као надређени појам који обухвата различите жанрове, све до савременог вица, а може се протегнути и на савремену књижевност и филм. Закључак ове шире класификације показује да пример личног наратива (овде запис под бројем 14) чува традиционалну слику света, чије су одлике инверзија и „условна статичност” (Делић 2015). Што се друге јужнословенске грађе тиче, сем Пиргове-Иванове, и Вихра Бајева објавила је две варијанте (Баева 2013: 151-153; 434-436). Мирјам Менцеј се у оквиру проучавања представа о вештицама осврнула и на искуства привремене смрти, као на врсту измењених стања свести која могу бити извор предања (Менцеј 2017: 387).

Као термини за опис појаве у наведеним примерима јављају се глаголи „обамирати”, „премирати” и „заносити се”, али и „умирати”, у једном случају чак и „тенчити се” (повампирити се). Неколико пута се говори и о снивању, очигледно као о синониму. У тексту бр. 15 истраживач пита информаторку за премирање, а ова јој одговара „спавам... као спавала сам”; и у примеру бр. 25 на питање о премирању, информатор говори о сну; у бр. 19 есхатолошко искуство саопштава се као сан, али се наративно не разликује од премирања. Теренски записи Д. Поповић Николић показују да на питање истраживача информатори, мада познају израз „премрети” у овом значењу, у жељи да објасне своје исказе, користе медицински термин „кома”. ${ }^{18}$ Овим информаторима познато је постојање саме појаве, али не и наративи: „То кад се умре да се поврати?... Као премире па се после поврати, и он то каже кад ме тамо, као, да је иш'о на онај свет па се врати, то то 'оћеш да...? - Е да, то било, то причали људи, то причали, као отидне там па се врати па после кад ће да умре." Индикативно је да се одмах на-

наблизу и надалеко голубли крила размахиваху зраком, дивотна лепотом, моћна величином, небројена множино [...]” (Настасијевић 1991: 39).

18 Заплање, село Сопотница, М. Н. (1944), С. Н. (1944) (Разговор вођен 2016). 
довезује приповедање о сну у ком се види покојник. ${ }^{19} \mathrm{У}$ другом примеру теренског рада видимо да на питање истраживача о премирању (,,jе ли била нека прича да је неко премирао?”) информаторка одговара: „Моја мајка била у кому" (23). Називање оваквих искустава сновима показује сродност дубљу од чисто описне и терминолошке, јер су приповедања о сновима веома слична приповедањима о привременој смрти.

Приметна је склоност информатора ка сродним темама. Тако информатор Снежане Марковић говори и о свом виђењу Свете Недеље (запис бр. 118), које мотивски подсећа на привремену смрт: наратору се у болести јављају светитељи; Света Недеља га опомиње због непоштовања празника и даје му упут за излечење, с тим да је убудуће празнује. Виђење оног света замењено је другачијом визијом, али остаје хришћанска обичајно-морална дидактика, карактеристична за легенду, саопштена кроз искуство ванредне животне и телесне ситуације. Могуће је говорити и о склоности казивача који чине „спроводник” (conduit) ка одређеној врсти наратива: отац Сретена Стојановића причао је и како је он сам видео отворена небеса на Богојављење. Важна је и наклоност самог записивача. Тако је 3. Пантић поред записа о посети оном свету објавио и један о видовњакињи која комуницира с покојницима и један о жени која признаје како се бавила црном магијом и била у ђавољем колу - оба у првом лицу, о необичним искуствима свести. ${ }^{20}$

\section{Структура. Мотиви}

Основне приповедне делове и мотиве можемо одредити овако.

1. На почетку се дају околности обамирања или уопштено саопштење о појави.

Један Премић однесен је да се сахрани; Обамирао човек, кад се повратио он прича; Умирао је човек; Занео се човек па се повратио; Заносио се човек па прича; Кад човек премире, прва жена стоји и зове га. Мој је отаи тако премирао и јавила му се прва жена (општа информаиија па прелаз на познато лице); Они који су обамирали па се повратили причају (опша информаиија); Један је човек заспао на гробљу и спавао 24 сата; Жена се тенчила, умрела. И дошли попове, опојали Ђу. И она седне у ковчегат и попат си побегал; А ово што сам ти причала, мој свекар исто и премирао, био мртав па се диг'о, био други разред у школу. То је истина било, кад је бо други разред у школу; И... премирала... „Па, ништа”, каже, „, пија Милена, ја”, каже, „спавам”, каже, „као спавала сам, иједан човек долази;

\footnotetext{
${ }^{19}$ Каоник, В. П (1949). (Разговор вођен 2018).

${ }^{20}$ „Како је баба Роса играла у ђавољем колу” (Расковник 73-73, 1993); „Како баба Станија зна шта се догађа на оном свету" (Расковник 63-66, 1991).
} 
Када сам премирао... Мој свекар био премиро, па видо. Видо како то. Па, то се напио, па премиро, није онако да умре. Моја мајка била у кому... Она премирала.

Запис бр. 14 пружа опширнији увод: од године преко околности поста до самог збивања. Делује оправдано посматрати овакве исказе као уводне формуле, блиске формулама предања по позивању на околности и истинитост. Изузимају се записи који препричавају предање.

2. Следи основни део, у ком се најчешће описује пуm $(2,3,8,10,11$, $13,14,15,16,17,20,24,25)$. Пут је некад само поменут, али се може јавити и опис другог света, који се креће од приказа раја и пакла до реалистичних детаља, на шта ћемо се вратити. На путу ка „тамо” стоји обележена граница. У приповедно разгранатијим варијантама, које можемо посматрати и као идеалтипски целовити модел, наратор среће две врсте оностраних бића (некад обе, некад само једну). Путем га води психопомпос: чича, Велика Госпојина, човек с брадом и књигом („,ветац”), с великом брадом, Света Петка, неименовани човек, два човека. Он га доводи до неког ког можемо назвати чуваром границе или судијом: Св. Аранђел, познати покојници, стражар, Св. Петар, неодређени „они” („горе ми рекоше”), „неки”, свеци, покојна жена, човек који пише, човек с брадом и жена у црнини, човек с брадом и штапом, човек и жена у црнини. То је често именовани светитељ или неко ко носи знаке ауторитета (брада, штап, књига), мада се могу јавити једноставно и познати покојници.

Када стигне до чувара/судије, саопштава се одлука-објашњење: посетиоца из света живих враћају, јер је установљена грешка - или је доведен пре времена, или уместо неког ко се исто зове $(2,3,4,8,9,11,12$, $13,14,15,16,17,19,20,24,25)$. Неке су варијанте веома редуковане у том сегменту (12; уп. 23), а у некима среће само једно натприродно биће које га одмах враћа назад. Неки кратки извештаји говоре само о виђењу познатих покојника. „Путнику” се некад саопшти и када ће заиста умрети: на благдан-преславу (2), одмах након смрти побратима (3), на Св. Јована (9), у 86. години (11), након годину дана (12).

3. На крају се описује пут назад, враћање у живот, а понекад и догађаји који потврђују сазнања стечена током боравка на оном свету. Као и код уводног дела, неке су формуле у првом лицу: Jа се вратим натраг. Ишао, ишао па се пробудио; И ја се вратих; Он напред, а ја за юим, и, каже, ја ти се пробудим погледам ти ја на сто лежим, преко мене, каже, и покров, све ме прекрили, ја устајем и вичем; Кад сам се ја разборавила", каже, ,, они ме и окупали и обукли и сандук направен”, каже, ,,све сређено; И вратише ме, каже, и ја отидо и пробуди се; То сам оживела у живот. 
Неке су у трећем: Вратио се натраг. Враћао се... Пипне уста, кад тамо, а оно два зуба фале. Он се онда сети да то није била коњска мрциина него његово тело; И мој деда кад се пробудио, тај га вратио. Оне укљчују приповедање о ситуацији које подразумева сведочење очевидаца: И дошли попове, опојали ђу. И она седне у ковчегат и попат си побегал. Сведочи се да је наратор умро онда када му је казано (2 - запис укључује казивање и у првом и у трећем лицу); Сећам се како је отаи на Светог Јована са узбуђењем отишао у село, а када се вратио саопштио је да је то јутро умро тај домаћин; Отии'о тај Милутин Ђорђевић куј требао да умре. Исто и бр. 11, 17, 20. Комбиновањем првог и трећег лица: Када сам поново оживео, истог дана умро је мој комшија Милан...

Поред иницијалних и финалних, могуће је одредити и формуле пута, веома сродне истим (паратактичким) формулативним исказима у бајци (вид. $2,13,15,17)$. Исказ судије којим се путник враћа назад такође се може посматрати као формулативан. ${ }^{21}$

Не треба превидети да је оно што смо у овој реконструкцији поменули као сусрет с познатим покојницима у тренутку самог приповедања вероватно имало наглашеније место у нарацији, ако не композиционо, а оно сигурно афективно: порука познатих са онога света.

Неки од наратива одступају од овог модела. Дучићев запис приказује индивидуални суд, али не над наратором, који је само сведок. Влашка варијанта из Зечевићевог описа повратак из света мртвих објашњава на неуобичајен начин, бежањем и лукавством. Мада је композициона функција иста, нагласак се премешта с одлуке натприродних бића на сопствену сналажљивост. Стојановићев запис усамљен је у томе што наратор има виђење сопственог греха из прошлости. Ово донекле подсећа на запис из Расковника (11), где се наратор приликом проласка кроз митарства присећа одређених грехова, али код Стојановића је реч о дословном виђењу. Петровићеви записи 4, 5 и 7 само су кратак извештај с оног света, било опис, било разговор с покојницима, исто као и бр. 26. Бр. 6 даје уводну општу информацију и кратко саопштење са саме „границе” преласка, где човек на самрти чује покојну супругу.

Како видимо, у једном броју записа користи се прво лице, у једном треће, што би одговарало подели на меморате и фабулате, која се користи за предања. У неким текстовима информатор приповеда о блиској особи, где се граница идеалног мемората и фабулата замагљује (уп. Degh 2001: 75-76). Пошто су у неким од ових варијаната извори чланови породице,

${ }^{21}$ Кринична (2005: 119-120), на основу руских примера, исказ натприродног бића којим се наређује повратак назива „семантичком вербалном формулом”. 
могуће их је посматрати и као део породичног фолклора. Код неколико записа приметно је пребацивање из трећег лица у прво приликом описа. Један наратив може да садржи казивање у првом лицу, маркирано одговарајућим формулама (уводна: „Идем све тако путем”, финална: „Ја се вратим натраг. Ишао, ишао, па се пробудио”), које је уоквирено казивањем у трећем, са његовим формулама (уводна: „Обамирао човек, кад се повратио он прича", крај-сведочанство о смрти наратора у првом лицу) (запис бр. 2). Запис бр. 13 има оквир у првом лицу, али нараторка је ту само сведок, који се присећа казивања свог свекра, тако да се брзо пребацује у пренос његовог првог лица. Уводна формула је сведочанство првог лица о трећем (То је истина било), потом се прелази на свекрово сведочанство, блиско формули пута (а а т тонем, каже, и идем). Након описа другог света, прво лице (виделац) опет формулом пута завршава визију (он напред а ја за њим и, каже, ја ти се пробудим, погледам ти ја на сто лежим...), да би се на крају његово сведочанство спојило са првим лицем информаторке (та баба-ја је нисам запамтила: извештај о смрти суседа као потврда доживљеног). Можемо видети, дакле, двоструку употребу формула у случају коришћења првог и трећег лица: у оквирном тексту и у „обамирању” које чини језгро. Бр. 15 показује исти поступак. Након што жена која се вратила с оног света закључи своје казивање формулом повратка, нараторка наставља казивање и заврши га спољном финалном формулом, која служи потврди: И, каже, врати се она $u$, $и$, каже, али живела шест месеичи по то и после умрела после. ${ }^{22}$ И у бр. 20 смењује се прво лице информаторке, треће лице (њен говор о деди) и пренет говор у првом лицу деде (што обликује различите формуле: И он води ме човек, води, и врати ме; И после се диго мој деда, живео коча по то) (Уп. и 23).

Лако пребацивање са трећег лица на прво, односно са управног говора на неуправни издвојено је као стилска одлика усмене прозе, нека врсте протоформе доживљеног говора (Бошковић Стули 1975: 162-171). Значај ових поступака у наративима о обамирању најбоље се може одредити сродношћу са истим поступком у предањима, жанру који се такође позива на истинитост. Преласком на прво лице информатор не даје пуку репродукцију ситуације приповедања којој је присуствовао, него тежи да врати снагу првобитног казивања. Ове поступке не треба видети стога само као општу одлику усменог стила. Анализом употребе лица открива нам

22 Запис бр. 9 даје пример првог лица само као слушаоца, који се опет позива на сведочанство неког другог. Уводна формула: „Отаи је причао... како је неки сељак говорио да је био умро...”; финална: „Сећам се како је отац на Светог Јована са узбуђењем отишао у село, а када се вратио саопштио је да је то јутро умро тај домаћин”. 
се суштина управо овог жанра: позивање на лични доживљај. Оно остаје крајњи извор нарације и њене легитимности и онда када је приповедни поступак разуђенији и приближен уоквиравању. ${ }^{23}$ Видећемо да управо то језгро личног доживљаја помаже у жанровском одређењу.

Посебан је проблем текстуализација. Како смо видели, неки су текстови савремени теренски записи, неки су етнографско преношење грађе (у том смислу значајни због мотива, али се тешко могу користити за анализу формула и наративних стратегија), а неки популарно публицистички. Употреба трећег лица понегде можда и није поступак информатора, већ записивачевог односа према преносу текста. Делује да су се приликом текстуализације највише „крзали” уводни и завршни делови. Савремени записи 14 и 15 добро илуструју сложеност овог процеса и можемо само нагађати да ли и наизглед једоставни записи Петровића крију иза фрагментарности исте процесе двостране комуникације који су нам данас изгубљени. У бр. 14 наратив се из транскрипта издваја стурктурално-мотивски, мада су формулативни искази опширнији, тешко сводиви на једну формулу (можда: „Шта је било с мене, ја не знам, само знам да сам у четр сата усто”; „Ниси ти још за овамо. То је рекла и друго није ништа рекла"). У запису бр. 15 се јасно издвајају формулативни делови који маркирају границе жанра: („,павам, каже, као спавала сам”; „Кад сам се ја разборавила, каже, они ме окупали и обукли и сандук направен, каже, све сређено"). Међутим, нека важна саопштења у ова два примера настају додатно, као одговор на истраживачева питања. У бр. 19 извештај о премирању даје се поводом сродног, али не директног питања. Опет, у књизи Тодоровића (запис бр. 17) оно што би у усменом казивању била финална формула, постаје написан, препричан извештај - али са истом функцијом. Бр. 18 се позива на породично преношење, али показује јасну дидактичку стилизацију, како у тону, тако и у истицању етичког кодекса.

Савремена српска фолклористика увелико је отворила питања употребе приповедних лица, ослањајући се на новија наратолошка истраживања (Самарџија 1997: 74-75. и даље; ${ }^{24}$ Поповић Николић 2016: 11-25), као и питања текстуализације усменог жанра (Ђорђевић Белић

${ }^{23}$ Употреба „каже”, која је издвојена као речца са снагом конјунктива (Бошковић Стули, исто), има у предањима двоструку функцију: дистанце, али и оснаживања истинитости, позивањем на усвојеност у традицији, на ланац преношења. Овде делује (уз несумњиво композициону улогу, сродну библијском „и”) као непрекидно подсећање на изворног говорника и његову ситуацију.

${ }^{24}$ Исти поступак у шаљивим приповеткама о надлагивању има сасвим супротну функцију: прелазак са трећег лица на прво наглашава невероватност исприповеданог (Самарџија 1997: 81). 
2012; Ђорђевић Белић 2015). Овде се на ту проблематику осврћемо из два разлога. Први је општијег карактера: само стање текстова који чине корпус (где за детаљнија могућа теоријска сагледавања упућујем на поменута истраживања). Други јесте однос ових проблема према основној теми - виђењу оног света. Јасно је да је кључно лично сведочанство, које „зрачи” и онда када информатор говори о неком другом и онда када долази кроз различите записивачке методе преношења саопштења. То позивање на лично помаже нам у жанровском профилисању текстова.

Посебну пажњу посвећујемо самом приказу оног света, где приповедни мотиви истовремено одговарају системима веровања. (Наравно, не сме се заборавити да су етнографске систематизације веровања као извор често имале саме приповедне жанрове: предања или наратива попут ових о премирању). У наведеним наративима препознају се теме добро познате из етнографских описа: за смрт је надлежан Св. Арханђео; на други свет прелази се преко воде, длаке, моста, брвна, даске, шипке - тај је прелаз често описан као изузетно узак. Други свет је инверзан првом, обележен неактивношћу: тамо нико не говори, храна се не једе. Одсуство звука је позната одлика хтонских простора, од античких религија до новијег фолклора. Други свет је на неки начин и привид људског: храна стоји на столовима, али је нико не једе; наизглед се чувају животиње, али се не мичу; покојник говори да животиње једу, али ни оне се не мичу. Барем према некима од ових наратива, други свет одликују тишина, непомичност, фантомска природа. („Ништа, ево гледам како људи раде. Нит има људи да раде, нит ишта. као, раде људи, њи нема”; „...и, овај, он тобож гони крмке. Ниш јок, ниђе се крмци не мичу" - бр. 14).

Уз сву свест о класичној опасности фолклористике да западне у дивљење пред „древним” и „очуваним”, несумњиво је: ови наративи пружају неке веома архаичне слојеве веровања. Можда је најилустративнији пример уског прелаза према оном свету, који је по свој прилици праиндоевропског порекла (Зечевић 1982: 29-32; уп. Лома 2002: 213). Није реч толико или само о очуваним фрагментима старе слике света, већ о веровању које је истовремено и древно и врло живо - сами наративи сведоче о њиховој животности. То је уједно само један део слике оностраног.

У два записа $(8,15)$ среће се исти мотив: повратак у свет живих дешава се уласком у коњска уста. Могуће је да је овде сачувано нешто од архаичне представе о коњу као хтонској животињи, везаној за смрт, често и гласнику смрти (СМ 2001: 280-283). Присуство овог мотива у две варијанте записане у великом временском распону и на различитим теренима наговештава стабилност жанра већу него што се на први поглед чини. 
Tonографија другог света је негде јасно хришћанска: јављају се рај и пакао $(1,11,21)$, мерење душа (1), митарства $(11)$, рајска врата $(9,13)$; негде пакао није именован, али су приказани или поменути грешници који се муче $(12,13,14)$. Наглашено хришћанског карактера је мерење душа у Дучићевом запису и опис митарстава (11). Мада се у високој теологији понекад расправља о правоверности ове друге замисли, на нивоу народног православља митарства су несумњиво прихваћена. ${ }^{25}$ Чак и ако би била пореклом из позноантичког успона кроз небеске сфере, утолико је фасцинантније видети њихову потоњу судбину у балканском фолклору 20. века, где живе као део личне исповести.

У некима је, међутим, онај свет без препознатљивих обележја хришћанства. Чести су помени шуме, ливада, птица, било у лиминалној фази пута ка оностраном, било „тамо” $(2,13,14,15,25,29)$. Цветна ливада као locus amoenus није можда именована као хришћански рај, али јесте место боравка душа у миру. Ни градина у бр. 15 није именована као пакао, али познати грешник тамо јауче. Као да је стање важније од јасног одређења места. Ово би деловало као нека врста наивне, спонтане реалистичке стилизације, да таква овостраност оностраног није истовремено део народне религије. И приказ оностране гозбе направљене од да̂ће, на први поглед реалистички, дубоко је укорењен у посмртне обичаје народне религије. У неким је наративима природа другог света лишена топографије карактеристичне за хришћанство као светску религију, па је пут или неодређен или одаје снажан тон народне религије, као што је сусрет са познатим покојницима, сусељанима, члановима породице $(4,12,14)$.

Ипак, поменуто разликовање хришћанске и народне слике другог света великим делом долази из етске визуре истраживача, дијахронијске или типолошке, јер у појави која се одређује као народна религија - у овом случају народно православље - како је познато, различите представе живе стопљене. (Није реч само о остацима претхришћанских слојева, за чим је фолклористика интензивно трагала, него и о фолклоризованој верзији светских религија). ${ }^{26}$

Етика коју нам приказују ови наративи је колико хришћанска, толико и обичајна, традиционална. Позива се на самилост и чињење добрих

${ }^{25}$ Главни извор јесте Житије Св. Василија, унутар ког се налази виђење преподобне Теодоре. Неки теолози, под утицајем историјског приступа, сматрају да је реч о изворно херметичким или гностичким космологијама и пнеуматологијама, док други указују на присуство замисли у другим патристичким изворима.

${ }^{26}$ Уп.: „Уосталом, сама подела есхатологије на књишку и народно-легендарну сасвим је условна: последња се у великој мери формирала под утицајем прве, а на апокрифе су одређен утицај извршиле древне паганске представе" (Грицевска, Пигин 1993: 52). 
дела (Дучић), кажњавају се завада браће око међе, прељуба, воденичар који је криво мерио, лопови, шверцери, паликуће. У Дучићевом запису чак и некрштена душа детета мора да испашта. Извештај са другог света подразумева да се даје даћа покојницима. За наратора се заузима његова крсна слава, Велика Госпојина, јер ју је славио. Са другог света потврђује $\mathrm{ce}$, рецимо, и обичај опасивања преминуле деце $(5,13) .{ }^{27}$

У неким варијантама обликовање оног света према свакодневици продире и у детаље, чиме се сасвим прелази у реалистичку стилизацију - чак се дешава туча, као на вашару (2). Инстанце вишег света јављају се као писар са актима, суд, жандарми. Говор информатора у бр. 14 снажно је реалистичан. (Овде се може навести и податак забележен код влашког становништва: да судије душу која је грешком дошла на други свет враћају на груб начин, шамарима и погрдним речима (Зечевић 1978: 387)).

Чест је мотив књига. Књиге и уопште писање у предањима о судбини јесу атрибути суђеница; постоји веровање у записану судбину и књиге судбине. Чак се у врло христијанизованом запису бр. 11, књиге у које анђели треба да погледају помињу као књиге „пресудњача”. Али ово се истовремено спаја са митизацијом књиге као објекта у руралној култури. Натприродна бића која из књига одређују ко треба да живи и умре имају аналогоне у разним општинарима, чиновницима и лекарима са којима су се наратори сусретали - отуда не изненађује што је реалистичка стилизација само на корак одатле. Ђаволи су „као неки одбор, као нека комисија”; наратор се позива да сиђе „ради хитне провере”; анђелима који су направили грешку каже се: „ви примате плату за бадава” (11). Књига судбине је златна, изједначена с библијском књигом живота (21).

Што се топографије тиче, изгледа да је кретање замишљено у хоризонталној равни. Један пример (12) експлицитно помиње одлазак „горе” (није јасно да ли је нараторка себе послала у рај), док обилазак пакла и paja у бр. 21 укључује кретање горе и доле, са детаљима око степеника (успон) и седам нивоа. Запис бр. 11 укључује кретање нагоре, али је оно везано за структуру митарстава. У организацији простора далеко већи значај има обележавање преласка. Време је везано за самог појединца (није му тренутак смрти, умреће у одређено време), што опет открива јаку личну перспективу. Ретко је сведочанство о два времена у два света у бр. 14, где наратор среће своју тетку која је млађа од њега, јер је умрла

${ }^{27}$ Уп. рецимо са описом Саватија Грбића: „Кад умре мало дете, онда нарочито пазе да га пашу, јер по народном веровању, мало дете на ономе свету бере цвеће, које меће у недра, па у вече доноси Богу. Ако је дете распасано, њему цвеће пропада и не може ништа да донесе, па зато непрестано куне своју мајку" (Грбић 1909: 244). 
као девојчица. Позната је представа да на оном свету време не тече и да покојници остају у добу у ком су умрли, ${ }^{28}$ али одатле наратор извлачи парадоксалну слику, утолико јачу што је везана за сопствену породицу. У бр. 26 покојница, која је умрла са четири дана, сад је девојчица (,порасла девојчица"); описује се и њена хаљина.

Лични извештај обликован је према традиционалним представама, а истовремено их својом непосредношћу потврђује - појава која је добро позната и код демонолошких предања-мемората. Постоје и неки други индивидуални доприноси наратора. Један је позивање на физички или готово физички доживљај. Наратор записа бр. 8 види сопствено тело као „мрцину”, удара га и по повратку у живот види да је изгубио зубе. У запису бр. 14 наратор говори о осећају дословног падања с терасе, пре него што му саопште да није за тај свет. У запису бр. 13 наратор чује кукање, а потом, пре формуле пута,: ,, а ја, тонем, каже”; у бр. 17 чује лајање, које му два психопомпа објашњавају као кукање мајке; у бр. 25 пружен је нејасан, заиста ониричан доживљај отварања неке главе и гурања главе информаторке „да прође”. Информатор (бр. 21) описује „упад” у тело и јак осет хладноће. Три пута поновљена реч „дивно” (30) наговештава снажан доживљај.

Наратор може и да орнаментализује текст. У запису бр. 13 схеми повратка у живот аутор додаје своју емотивну реакцију. Цела је варијанта прилагођена детету: натприродна бића га враћају на превару говорећи му да чита књигу, а он је по буђењу тражи и плаче. Описи луга могу бити нешто развијенији: „Трава ова”, каже, „жута рада и бела цветале”, каже, „то се само жути и шарени, а они беру они цветићи, праве венчићи, па стављају”, каже, „на главу. А вране”, каже, „оно док сам жива, ја има да памтим. То сам учинило”, каже: „Гааа, гаaа, гаaа!” (15). Или: „Тице певају, дан леп, право пролеће" (2). Када јој се заповеди да уђе у коњска уста, нараторка коментарише: „Па нисам шашава да ме поје коњ”. У тексту бр. 21 наратор убацује више пута хуморне коментаре (како је хтео да украде књиге живота када их је спазио; да рај мирише лепше од „шанела пет”; кад види светло које је Бог, пита Св. Јована „Је ли то шеф?”).

Када је о личном доприносу реч, задржаћемо се на опширној варијанти из Расковника, уз свест о њеној могућој стилизацији. Наратор придаје доста пажње осетима: по ливади иде као по свили. „А ја некако лак па не напипујем земљу, све тако одозгор ...” Небо је зелено и топло, као за летње месечине. Наглашен је визуелни аспект: људима тамо сија

${ }^{28}$ Као да бр. 12 наговештава проток времена: „Кола и мојта черка ка пуштиле перчиње, од милине да ђи гледаш"; али можда је реч и само о опису лепоте. 
сјај из лица, јачи од сунца; Велика Госпојина има хаљине које светле од себе. Јавља се и звук: оностраним бићима речи звоне као црквена звона; чује се урлање; „све пуца, тресе се и мешкољи”. Овде је и редак опис индивидуалног суда, вађења душе, праћен губитком осета у доњем делу тела и болом у грудима. Демонска бића у јами у коју је бачен сликовито су описана као: „створења која немају ни очи ни кожу, него им месо дрхће као пихтије". Смрт је страшна ала која не може да се опише. Опис митарстава верно следи црквену лествицу. ${ }^{29}$ Међутим, када се нађе на четрнаестом митарству, посвећеном прељуби, наратор има занимљиву интервенцију. Претходна је прошао јер греха или није имао или их је било сасвим мало. Овде се, међутим, исповеда како је био склон распуштеницама и прескакању плотова и питање је како би прошао да није - на напетом месту приповедања - дошла заповест да га врате, јер је установљена грешка. Заправо, оно што делује као исповедање греха јесте хвалисање. Остали су греси узети као прави греси али код овог греха наратор не жели да буде недужан. Немогуће је не осетити призвук хумора, који следи након застрашујућих описа ђавола. На крају, додуше, након исповести свештенику, наратор саопштава да се више није упуштао у такве подухвате - али ово одрицање од каријере сеоског швалера приповеда старац који говори о младом добу.

Приповедање Ђоке Будића потврђује црквено учење о митарствима. Чак он приповеда о њима као о збивању које му је као концепт непознато, а које му тек накнадно објашњава сеоски свештеник („касније кад сам му причао, поп Стева ми рекао да су то митарства"), чиме се потцртава утисак непосредности и аутентичности. С друге стране, наратор записа бр. 14 , мада даје прилично традиционалну слику оног света, своје искуство користи за проповедање сасвим индивидуалног односа према религији, супротстављеног црквеном - он пориче други Христов долазак, који је једна од основних догми, део Вјерују. Извор овог хетеродоксног става је лични сусрет са Христом и Богородицом. Како видимо, у једном се случају доживљај користи за легитимизацију постојеће слике света, у другом за исказ приватне религиозности. Изазовно је у оваквој индивидуализацији догми видети одлику новог доба, чија је одлика и формирање личне религије, али не треба заборавити да је и у друштву које обично зовемо традиционалним било могуће индивидуално формирање слике света Гинзбургов млинар Менокио довољно сведочи о томе.

Пример бр. 21 пружа с једне стране традиционално обилажење раја и пакла, али са доста индивидуализованих нијансирања. Информатор

${ }^{29}$ Редослед митарстава према: Поповић 2004: 715-721. 
користи не само теме из народног православља, већ и библијске слике највероватније преузете из лектире (24 старешине су из Откровења, гл. 4). Међутим, наглашава да и поглавари источне и западне цркве иду у пакао (он их је видео), уз дигресивно критиковање свештенства, као и да рај није само за хришћане. Ова индивидуализација добија пун смисао на врхунцу нарације, кад Христос даје задатак информатору да поучава и помаже. На овој оностраној повести и упутству И. С. - који се бави исцелитељством и, како се види из интервјуа, брине због законских забрана - заснива свој исцелитељски ауторитет. Његови коментари о црквеној јерархији као да откривају ривалитет у ком он на својој страни има визионарско искуство.

\section{У жанровском систему}

Ови се наративи несумњиво могу подвести под категорије belief narrative или sacred narrative. Ово су кровни термини чија употреба треба да послужи лакшем споразумевању фолклориста, да се не би сваког пута залазило у класификације појединих текстова, али нас не ослобађа потребе да се спустимо на прецизнији ниво. Како је већ неколико пута напоменуто, позивањем на лични доживљај сусрета са натприродним најближи су демонолошким предањима, тачније меморатима. Они који говоре о доживљају трећих лица су, наравно, позивањем на конкретно име блиски правим предањима или фабулатима. Међутим, по слици света, атмосфери и односу човека и натприродног, од демонолошких се предања разликују. У предању натприродно упада у људски свет; овде човек одлази у свет мртвих. Натприродно у предању је свет ниже митологије, а сусрет с њим је по човека кобан. У наративима о виђењу другог света натприродно је често хришћанско, али и тамо где топографија оностраног не носи јасне хришћанске симболе, нема атмосфере угрожености човека, коју је Макс Лити маестрално описао у својим познатим студијама о предању. Ако у демонолошком предању демон стоји у центру, а човек сноси последице након наглог контакта, у овим наративима осећа се присуство поретка. Психопомпос спроводи човека до „више инстанце”: поредак, најбоље изражен у слици књига, подразумева да се зна ко који редом умире, грешка се исправља. У демонолошком предању два света су просторно близу, али је прелаз границе нагао и драматичан, за човека погубан. У овим наративима постоји одређена постепеност улажења у други свет, макар то било приказано само формулом пута. Језгро оба жанра је позивање на изузетан доживљај, али су слике света различите. (Ради јасноће напомињемо да као и у случају мемората, под доживљајем мислимо на 
позивање на доживљај, односно доживљај као приповедну стратегију и као део наративног света).

Без жеље да се ионако сложена терминологија фолклористике додатно оптерећује, делује ипак да би о овим текстовима најбоље било говорити као о есхатолошким меморатима. Есхатолошка предања дефинишу се као она која говоре о колективној есхатологији (смаку света). Међутим, како се у религиологији говори о колективној и индивидуалној есхатологији, односно о оној која се бави крајњом судбином света и оној која се бави посмртном егзистенцијом, постојање оваквих наратива оправдава узимање термина есхатологија у значењу које покрива и судбину појединачне душе после смрти. ${ }^{30} \mathrm{Ca}$ другим жанровима ови наративи деле представу о простору који се састоји од два света разграничена јасном међом, а коју јунак прелази уз помоћ медијатора. Таква слика простора среће се у бајкама (Радуловић 2009: 44-53), као и у приповеткама о судбини (тип Усуда, в. Радуловић 2012: 340-377). Онострано бајке је апстраховано, док је овде везано за жива веровања и непосредну човекову заокупљеност питањима смрти, а често и судбине блиских покојника, али та сродност подсећа на теорије (Пропа, Лотмана) о пореклу бајковног простора и сижеа о одласку „тамо” у архаичној представи о посети царству мртвих. Улога Усуда као бића које одређује судбину, смештеног у други простор, вероватно хтонске природе, подсећа на улогу судије у овим есхатолошким меморатима. Како и епске песме и баладе често поседују ову дводелну слику света с границом (Детелић 1992; 1996: 99-101), очигледно је реч о неким дубљим представама о простору које су срасле са приповедним стратегијама. Односно, тематска сродност појединих жанрова долази од наслеђа заједничке древније слике света. Пролазак кроз онај свет са водичем и виђење посмртних судбина блиски су и стиховном жанру легендарних песама. Ове друге су још од 19. века поређене са апокрифима, који се сматрају њиховим крајњим извором. Примећено је одсуство прозних варијаната (сем кратких саопштења о веровањима). Можда овај корпус управо допуњује жанровску лакуну, која почива на истој „заједничкој тематско-сижејној основи" (Милошевић Ђорђевић 1971: 204-213).

Постоји сродност легендарних песама - као и једног броја наратива о посети оном свету - са приповеткама типа ATU 471 (The Bridge to the Other World) (нпр. „Очина заклетва”, Вук 17; Чајкановић 1928, 168 - у пратећим коментарима дају се и друге варијанте): у њима натприродни водич такође води јунака кроз други свет и показује награде и казне

${ }^{30} \mathrm{y}$ есхатолошким предањима стабилни су делови етички мотиви греха и казне, док у овим есхатолошким меморатима њих нема увек. 
са снажном потком традиционалне етике. Ова врста структуре, блиска алегорији (слика-објашњење са дидактичком намером) јавља се и у сложеним приповеткама попут „Усуда” и у блиском типу ATU 759 (Анђео $u$ пустиғак), који већ припада легендарним приповеткама.

И неки од ређих примера које смо навели имају паралеле. Дучићев запис подсећа на егземпле. Наратор не доживљава суд над собом самим, већ је само сведок збивања, а ни учесници нису познати покојници из села, већ готово типски ликови, попут немилостивог цара. Подсећа се да и наизглед најневинија душа, као што је дечја, има грехова. (Можда је управо то што признаје свој грех одводи у рај без мерења на теразијама). Влашка варијанта коју наводи Зечевић подсећа на приповетке о варању смрти (нпр. ATU 332), више општом темом, него мотивима.

Сродности са другим приповедним формама постају јасније оцртане када се уведу они жанрови који нису нови, али које фолклористика тек од скора издваја у својој таксономији. Приповедање о посети оном свету се несумњиво подудара са приповедағима о сновима, која се и у српској фолклористици у новије време издвајају као засебан жанровски корпус (Ђорђевић Белић 2019; 2020, управо снови о покојницима). Чак је и на нивоу именовања стања приметна сличност и заменљивост, како смо видели. (в. примере 19 и 20: први се даје поводом интервјуа о сновима, мада информатор користи термин ,премирање”, а други се и саопштава као сан али тематски и структурално потпуно одговара „премирањима”). Постоје разлике и у приказу кретања. У есхатолошким меморатима наратор иде на онај свет, док је у сновима већи степен варирања: сневач може да иде тамо, али и мртви могу да дођу њему, или је приказ простора неодређен. С. Толстој издваја шест разлика: обамирање није нормална ситуација сна, већ натприродно схваћена летаргија; у „обамирањима” је виделац активан учесник; сцене су поучног карактера; постоји и лик вође; стиче се тајно знање, попут времена сопствене смрти; наративи су јасније жанровски и сижејно оцртани од наратива о сновима, нарочито када је о структури реч (Толстој 2002: 212; в. већ наведен део из: Сафронова 2016). Необична варијанта у којој се коњска стрвина из виђења разоткрива на јави као сопствено тело подсећа на принцип тумачења слика сна у фолклору.

Алегоријски принцип разрешења слика, какав се јавља у легендарним приповеткама, такође је близак фолклорном разрешењу снова (једна слика - једно значење; више о томе у: Радуловић 2003).

Тематски посматрано, уочљиве су сличности и са различитим наративима који почивају на измењеним стањима свести, као што су казивања о трансу, у различитим контекстима и жанровима. Ту би требало поменути 
предања о вилама и здухаћима. Реч је о тематској сличности, али пажљивије поређење би могло открити и неке структуралне разлике. Исто важи за наративе о излечену. У најширој перспективи и шамански наративи о посети оностраном морају се неизоставно поменути овде (а шаманизам је могући извор и неких од тема европских предања): није им заједничко само језгро посебног менталног стања, односно позивања на њега, већ и мотиви кретања, преласка границе, сусрета са помоћником-водичем.

Компаративно, овај жанр се подудара са изученим руским примерима. Једна особина којом се разликују је то што у српским примерима не срећемо забрану да се по повратку у живот говори о виђеном, која се јавља код руских текстова.Ова сродност источнословенских и јужнословенских примера тек захтева детаљнију анализу. Упадљиво је и да се влашка варијанта разликује - и ту треба утврдити да ли је реч о индивидуалном доприносу информатора или пример показује дубље ареалне разлике.

Показује се да овај корпус другим прозним жанровима дели низ мотива и поступака, чиме је укорењен у фолклорној традицији, а особеностима као што су позивање на доживљај и слика света издваја се у овом спектралном прелазу између сродних облика.

Писана традиција, прелазни облици, савремени наративи

Јасна је сродност са средњовековним апокрифима и виђењима, хебрејским и другим источним, византијским, словенским и западноевропским. Они имају дугу традицију, која се од Блиског истока, као извора, протеже и на даљи простор, како показује зороастрејска Кюига Арда Вирафа. Зато се типолошко и историјско проучавање не морају искључивати: сличности усмених варијаната са неким древним књижевним сведочанствима долазе и отуда што велик број апокрифа, који је можда непосредно утицао на фолклор, укључује у себе наслеђе старе блискоисточне литературе.

Неопходно је подсетити да ти текстови нису ограничени на средњи век, већ се у виду књига за народ њихове верзије, или барем њихове теме, протежу све до данас. Књиге о митарствима се у виду популарних црквених публикација код нас континуирано објављују од 19. века. ${ }^{31}$ Тај

${ }^{31}$ Нпр. 1860. (бугарски превод, али у Београду); Житије преподобног Василија Новог и виђеније његовог ученика Григорија о митарствима (Велика Кикинда 1896); Житије преподобног оияа нашега Василија Новога и опис о проласку ваздушних митарстава блажене Теодоре (Крагујевац, 1931), Живот преподобне Теодоре и ваздушна митарства (Крагујевац, 1976); Пут душе после смрти: житије преподобног Василија Новог: о митарствима (Ваљево-Ћелије, 1973; 1985); Путоказ у Царство Небеско (Света Гора - Манастир Хиландар, 2006 - укључује 
континуитет може бити важна тачка у неком будућем проучавању књига за народ. Нека издања објавила је Православна народна хришћанска заједница, односно богомољачки покрет, чија је улога у формирању народне побожности у 20. веку позната. Неке од ових књига изведене су из списа Николаја Велимировића (који је био задужен за богомољачки покрет) и Јустина Поповића. Јустин Поповић је митарства унео и у своју Догматику. Присуство ове теме и у високој теологији и у књизи за народ сведочи о распону у ком је срећемо и у савремено доба. Митарства нису у усменим наративима толико честа, већ их овде наводимо више као пример како старе религијске теме, обично везане за средњовековне апокрифе, могу бити живе и данас. Односно: оно што је старија наука у усменим варијантама видела као наслеђе средњовековне књижевности, може бити и део савременог народног живота. Као друге примере можемо поменути постојање апокрифа Мати Божија у паклу и Дванаест Великих Петака и Страшни cyд као књига за народ, од 19. века до међуратног периода (издвајамо само оне који су везани за есхатолошке теме). И књиге које нису редакције старих апокрифа одржавају ове теме живима (в. нпр. Пред Други долазак Христов А. Мијовића, Крагујевац, 1928, са снажним апокалиптичким тоном; Кроз врата смрти, превод мађарског изворника преко бугарског као језика посредника, свештеника Миодрага Михајловића, Ниш, 1960, о индивидуалној есхатологији). Књижица Повратак из онога живота. Чудесно виђење монахиње Евпраксије, коју је с грчког превео Атанасије Јевтић, а објавила Православна народна хришћанска заједница и Црквена општина Крњево (1978), описује како су током тродневне привремене смрти монахињу (тад мирјанку) арханђео и благородна Марија провели кроз онај свет и показали јој рај и пакао. Неки мотиви подударају се с онима из „премирања”: сусрет с познатим суграђанима; сусрет с човеком који има књигу где се уписују имена оних који долазе. ${ }^{32}$ Као занимљивост издвајам књигу нишког пароха Ивана Петровића На путу кроз пакао до раја (Ниш, 1984): поред разматрања посебног суда, раја и пакла, навођења примера контаката живих и мртвих упућује се и на књигу Рејмонда Мудија Живот после живота, дело које је подстакло талас интересовања за „искуства блиска смрти". Мада је овај феномен, како га Муди представља, теолошки одбачен као стран православној есхатологији, овде се наводи као пример доказа посмртне егзистенције (стр. 21).

Живот блажене Теодоре и ваздушна митарства); Митарства: како их је објавила преподобном Григорију блажена Теодора после своје смрти (Костолац - Манастир Рукумија, 2001).

${ }^{32}$ Аутор грчке књиге је Амфилохије Макарис, духовник женског манастира на Патмосу. Сам догађај смештен је у 1900. годину. 
Савремени живот старих писаних жанрова остаје истраживачки дезидерат у ком заједно могу да се нађу фолклористи, који би изучавали црквени и прицрквени фолклор, етнолози и медиевисти-филолози. За пример из збирке С. Марковић (13) Т. Јовановић сматра да показује управо утицај апокрифног Откровења апостола Павла (Јовановић 2009: 17-18). Календарска варијанта (бр. 18) пример је „народске” литературе у којој се спајају апокрифи, фолклор и намена „за народ”.

Лични наративи показују улазак старих - а истовремено и данас присутних тема - у лични доживљај. Пример бр. 11 прати виђење преподобне Теодоре не само у успону кроз митарства већ и у уводном делу. Она саопштава у првом лицу како је доживела растајање душе од тела; сусрет са ђаволима који буче; појаву светлих анђела; појаву персонификоване смрти; разрешење душе од тела праћено физичким болом и одузетошћу. Ђока Будић: „Кад оно, чини ми се, немам доњи део тела, немам ни руке...” Блажена Теодора: „И ја не имађах руке ни ноге, и цело ми се тело умртви...” (Поповић 2004: 713). И ликовне представе црквене природе могле су утицати на одржавање неких тема. За њих важи исто што и за апокрифе: није реч само о старим фрескама, већ и о новијим, као и о ликовним прилозима популарних публикација.

На крају, наводим један штампани текст који је обликован према схеми есхатолошког мемората. Године 1983. Душан Јовановић објавио је књижицу Визија, у којој описује своје виђење раја и пакла, датирано на 11.07.1976, када је имао 48 година. Он приповеда како је на путу ка Жичи и Матарушкој Бањи повезао калуђера и калуђерицу који су стопирали. На његово изненађење, двоје сапутника, којима се појављују ореоли, знају све о његовом животу, опомињу га на побожнији живот и наговештавају да ће му се десити значајан догађај. По доласку у Бању доживи психичку кризу, а потом у соби, након осећаја бола у грудима, пада у дубок сан. Појављује се анђео који му открива да је возио Св. Петра и Св. Петку. Анђео Гаврило га води у висину, показује призор будућег васкрсења мртвих и објашњава бесмртност душе. Пролазе кроз капију, а потом кроз „станице” стазом која постаје све ужа и ужа, односно кроз сунчеве сфере. Душан има прилике да види рај, са дрвећем, плодовима, птицама, кристалним потоцима, храмовима од драгог камења. Среће светитеље које је тог дана повезао, који га још поучавају. Такође види распетог Христа и издалека божји престо. У паклу се налази море пламена, огромне змије, црви и сличне животиње које прождиру грешнике. Анђео показује различите категорије васкрслих и посебно различите категорије грешника, уз каталог грехова. Анђео га опомиње како да живи и поучава, након чега се наратор буди у соби. Остатак текста је приповедање о преображају, покајању и окретању религији, према чему усмерава и своје чланове породице, исповеда се и причешћује. 
Рецепција овог текста у црквеним круговима тек треба да се испита. Површан поглед на интернет показује позивање на њу на црквеним, али и другим форумима, док је pdf верзија доступна за скидање на сајту цркве св. Ђорђа на Бановом Брду. ${ }^{33}$ Одломак из књиге унет је и у једну католичку антологију небеских виђења, као на пример „визије једног православца” (Цветковић 2000: 55-61). Занимљиво је да је ауторов брат Милован Јовановић, иначе информатички образован, деведесетих водио њу ејџ групу „Карма центар”, која се бавила „каналисањем” (channeling), спровођењем текстова космичких интелигенција. Заједно са Маријом Реић, Милован је објавио збирку порука које је примио од Космичког разума, под насловом Семе космичког знана (две књиге, 1993) (Радуловић 2020: 295-298). То је један од ретких примера каналисаних текстова код нас. Милован помиње визију свог брата с дистанцом, као што и Душан помиње Милована као безбожника. Два брата су објавила текстове који приказују онострано, али на сасвим различите начине. Душанов је у традицији црквених виђења, док је Милованов на линији њу ејџа (са генеалогијом у старијем спиритизму).

Увод Визије сасвим подсећа на народну легенду о сусрету са непрепознатим светитељем. Савремена „сценографија” подсећа на „урбану легенду" о сабласном аутостоперу, само се ова верзија из аветињског угођаја враћа у хришћанску легенду. (Додуше, и неке варијанте „сабласног аутостопера" садрже хришћански тон, нпр. натприродни сапутник обзнани да је близу смак света или други Христов долазак и потом нестане). Аутор се не позива на клиничку смрт, али сан који описује, а нарочито бол у грудима, подсећају на „премирање”. Паралела у народној традицији имају и каталози грехова и мотив уског прелаза. Успон уз сфере више одговара писаној традицији апокрифних виђења.

Књига Душана Јовановића нашла је свој пут у усмено преношење. Године 2003. Марија Илић је у колективном прихватном центру у Калуђерици водила разговор са В. Г. (1934) из Велике Хоче, који је објавила Светлана Ћирковић (2009). ${ }^{34}$ Мада се информаторка не сећа наслова књиге, јасно је и по садржини опширног наратива и по имену главног јунака да је запис препричана књига Душана Јовановића. Књига је у начелу верно пренета; делови виђења раја и пакла су нешто сажетији него у штампаном изворнику, као и успон кроз сфере, док отприлике половину овог дела транскрипта чини опис конверзије након визије; чак и сам прелазак

\footnotetext{
${ }^{33} \mathrm{https}$ //hramsvgeorgija.rs/download/vizija-o-raju-i-paklu/.

${ }^{34}$ Интервју настао у оквиру пројекта „Истраживање словенских говора на Косову и Метохији (2002-2003)", који је финансирао УНЕСКО. Грађа се чува у Дигиталном архиву Балканолошког института. Консултован и снимак: 114-Р-Дреновац-5-МИ.
} 
у измењено стање свести губи оштрину коју има код Јовановића (бол у грудима).

Информаторка се неколико пута позива на књигу коју је купила у цркви, а коју јој неко није вратио. То је сведочанство о животу и ширењу овакве литературе, о миљеу народне побожности и фолклору тог миљеа, али се у њеним речима осећа и нешто од поштовања за штампано слово и књигу као објект. (Иначе је радила у Богословији у Призрену). Закључак С. Ћирковић је: „[...] анализирани наратив показује да је однос наше саговорнице према традицијској култури углавном динамичног карактера и да показује промене. Промену од колективног према индивидуалном налазимо у чињеници да сама саговорница бира шта ће испричати као потврду за део културе који се преноси традицијом [...]". Управо се препричана Јовановићева књига наводи као пример замене колективне религиозности индивидуалном (Ћирковић 2009: 221). Тај наратив истовремено илуструје прелазе између усменог и писаног, пример апокрифног наслеђа, амалгамисаног са народним представама, као део прицрквеног фолклора.

Наративи о виђењу другог света очигледно могу привући и пажњу других дисциплина. Личним приповедањем о смрти и виђењу оностраног у самом смо језгру религијског доживљаја, тако да се могу посматрати и са становишта науке о религији и антропологије. Типолошка проучавања отуда ове текстове пореде не само са старијим примерима (визије, апокрифи), него и са већ поменутим модерним извештајима о привременој смрти (near-death experience - NDE) и са извештајима о НЛО отмицама. Појава Мудијеве књиге (1975) подстакла је низ сличних публикација, увела појам у популарну културу и привукла пажњу низа дисциплина, укључујући психологију, психијатрију и неурологију, тако да су се и фолклористи осврнули на сличности. Тодорова Пиргова (1999) наводи два примера бугарских „градских екстрасенса”; В. Бајева на основу доступне јој грађе разликује „модел Еноха” (карактеристичан за апокрифе) и „модел тунела" (савремена NDE). (Поређења између есхатолошких мемората и NDE наводи и Вигзел 2005). Левкијевска наводи да NDE који се приповедају у Москви показују одвајање од традиционалних наратива и јасан утицај Мудија (Левкиевская 1997: 810).

Овде у таква поређења не можемо улазити јер у српском корпусу доступном за овај рад немамо сведочанства која би одговарала савременим NDE. ${ }^{35}$ Познати ми примери позивања на NDE или само клиничку

${ }^{35}$ Иначе је преведено више књига о тој појави. Једна књига домаћег аутора о NDE (Драгољуб Павловић, Има ли живота после смрти, Београд, ауторско издање, 1990) компилација је примера из стране литературе. 
смрт, без описа оностраног, срећу се у савременом исцелитељству и сродним струјама, као стратегија легитимизације моћи коју исцелитељ поседује. Такав је и пример бр. 16 из књиге Тодоровића, где исцелитељ с другог света добија ауторизацију, а сама структура његовог наратива је традиционална. Исту функцију има већ разматран пример бр. 21, који иначе у два детаља открива да информатор познаје и савремене наративе о NDE. Један је поменуто посматрање сопственог тела. Само по себи оно није модеран мотив - може се наћи и у руском црквеном споменику 17. века (Сафронов 2008), исто као и у Повратку из оног живота - али будући да га у другим казивањима о премирањима не срећемо, а да је врло чест у модерним извештајима о доживљајима клиничке смрти, највероватније је да је наратору дошао из новијих извора. ${ }^{36}$ Други је један лапсус: када информатор описује божји дворац изнутра, саопштава како је у великој дворани кренуо ка светлу које је Бог (питајући ,је л' ово шеф?”) кроз тунел, али се одмах исправља и каже „хол”. Очигледно је помен кретања ка светлу асоцијативно изазвао представу о кретању кроз тунел из NDE наратива, али се казивач тргао и пребацио у традиционалније осликан рај.

Видовита Шехерезада у својој биографији истиче клиничку смрт коју је доживела са 17 дана, којом приликом се њена сестра близнакиња није вратила у живот. ${ }^{37}$ Ипак, она је скромнија од Зорана Петровића Шумадинца, биоенергетичара и исцелитеља, који тврди да је имао ништа мање него три клиничке смрти. ${ }^{38}$ Из друге руке ми је познато да се на привремену смрт позива и једна видовњакиња са Новог Београда која се медијски не експонира, као и да један исцелитељ као тренутак стицања моћи наводи струјни удар. Детаљно је о својим таквим искуствима писао Ратомир Вучковић, звани др Вук, аутор неколико књига о магији и астрологији објављених крајем осамдесетих, почетком деведесетих, а потом вођа неошаманске групе „Древни корени”. (Упркос овом „др”, Вучковић није имао лекарску титулу; изгледа да је својевремено радио у контроли лета на београдском аеродрому). У књизи Живот Вучковић тврди да је привремену смрт доживео неколико пута. „Драо сам се из свег гласа, али изгледа да ме нико није чуо. Покушао сам доктора да ухватим за руку, али моје тело је само млитаво лежало, више и не поскакајући од електрошока. Скотови! За мене то није као да сам добио одговор Мртав си,

${ }^{36}$ Он се поводом свог доживљаја позива и на визионарски исказ једног Руса који је гледао на Јутјубу.

${ }^{37} \mathrm{http}: / /$ vidovitaseherzada.net/bs/o-meni-2.

${ }^{38} \mathrm{https} / /$ www.telegraf.rs/vesti/srbija/3024362-zoran-sumadinac-tvrdi-da-isceljuje-posle-3klinicke-smrti-i-da-je-izlecio-sebi-tumor-emitujem-energiju-preko-skajpa-i-vajbera-predvidjambolesti-video. 
прихвати то! Гледао сам себе и био љут на то издајничко тело. Псовао сам. У десном углу, плафон се нагло отворио. Поред заслепљујуће дневне светлости, продрло је и нешто као отвор. Благо ротирајући, тај је отвор красио нешто као тунел; осећао се мирис првих љубичица. Био је то један леп, нежан позив (можда тако Рај мирише)”. Опис натприродног овде завршава, јер се у даљем току приповедања др Вук буди у мртвачници. Такође, са̂м саопштава да није дошло до драматичне промене у његовом животу, већ да је и даље наставио са животом који оцењује као лош. Други пут, десет година касније, имао је мождани уместо срчаног удара, али су га астрална искуства, која је у међувремену стекао, припремила за вантелесни доживљај. „Око мене су се врзмали неки ликови, укључујући и давно покојног стрица. Управо ме он нешто намргођено гледао, као запутио сам се где ми није место.” Након два дана вантелесног лутања по околини, вратио се у тело (Вучковић 2009: 203-206). Треба рећи, мада је у кругу својих ученика Вучковић наступао као гуру, да у овим описима не глорификује себе, већ наглашава своје мане и слабости. Није нам пружен непосредан драматичан приказ посвећења или преобраћења, али можемо осетити да на дуге стазе овакви описи дају потврду његовом шаманском и учитељском положају. У свим овим примерима, реч је о стварању изузетне биографије која садржи неки драматични прелом као извор моћи или знања. Међутим, наративи „обичних” информатора о NDE код нас тек треба да се сакупе. Колико ми је познато, ни психолози, психијатри и неуролози нису истраживали примере с нашег терена. Да су слике оностраног из популарних представа подстакнутих савременим NDE већ довољно ушли у хоризонт очекивања, сведочи усмено саопштење једног психијатра да су се неки пацијенти који су доживели „клиничку смрт” повратили разочарани што нису видели ништа од онога за шта су чули: ни тунела, ни светла.

Могуће је дати једну општију напомену поводом NDE и фолклорних наратива. Типски образац, како га даје Муди, подудара се са наративима које истражујемо: умирући чује буку; креће се уским, мрачним тунелом; посматра с дистанце сопствено тело и опажа ново тело које поседује; среће покојне сроднике и пријатеље, а онда и светлосно биће, пуно љубави, које му приказује протекли живот; потом схвата да није још дошло његово време и враћа се у тело (Муди 2007: 17-18). (Мудија узимамо као примарни извор, не као студију; занемарићемо засад другу литературу деривирану из њега, а превођену и код нас). У том смислу, са становишта фолклористике, могуће је посматрати га као жанр. Међутим, дубинска, суштинска промена јесте губљење традиционалне слике света, као и јас- 
них етичких, обичајних норми које онострано награђује или кажњава. Не изненађује отуда што су теолози реаговали на ширење овакве представе о оностраном (међу првима још Серафим Роуз - вид. 1995): уместо места награде и казне, NDE нуде безусловну љубав. Мада је намена теолошких текстова другачија, правилно је примећено да NDE потичу из деветнаестовековног спиритизма, теозофије и сродних окултних покрета, па се у савремено доба спајају са њу ејџом. ${ }^{39}$ Будуће истраживање неких домаћих NDE наратива - ако се пронађу - имаће прилику да покаже које су сличности и разлике на приповедном нивоу између њих и традиционалних есхатолошких мемората.

\section{ИЗВОРИ}

Вучковић 2009: Ратомир Вучковић - др Вук, Живот, Суботица: Изис.

Грбић 1909: Саватије Грбић, Српски народни обичаји из Среза Бољевачког, СЕ3 14, Обичаји народа српскога, књига II, Београд: Српска краљевска академија.

Деврња 1938: Милутин Деврња, Некролог. Смрт Момчила Настасијевића, Хришћанска мисао, IV/1-4, Београд, 27-28.

Дучић 1931: Стеван Дучић, Живот и обичаји племена Куча, СЕЗ 48 , Живот и обичаји народни 20, Београд: Српска краљевска академија.

Ђорђевић 1958: Драгутин Ђорђевић, Живот и обичаји народни y Лесковачкој Морави, СЕЗ 70, Живот и обичаји народни 31, Београд: Српска академија наука.

Златковић 2007: Драгољуб Златковић, Приповетке и предања из пиротског краја. Део II - предањ , Београд-Пирот: Институт за књижевност и уметност, Дом културе Пирот.

Јовановић 1928: Радован Јовановић, Календар Просвета, Сарајево, 1928, 166-167.

Јовановић 1983: Душан Јовановић, Визија о рају и паклу. Моје духовно обновљење, Крагујевац: Екуменски савет цркава у Југославији.

Марковић 2004: Снежана Марковић, Приповетке и предања из Левча. Београд-Крагујевац: Чигоја штампа - Центар за научна истраживања САНУ и Универзитета у Крагујевцу.

${ }^{39}$ Наглашавам да је ово на нивоу академске теологије, док ниво народног веровања тек треба да се истражи. Један разговор свештеника са неофитом (превод са руског, објављен на домаћем православном сајту) наводи управо NDE, описан сасвим као код Мудија, као тренутак преображаја (http://www.manastir-lepavina.org/vijest.php?id=8595). 
Мијовић 1928: Андреја Мијовић, Пред Други долазак Христов, Крагујевац.

Михаљфи 1960: Акош Михаљфи, Кроз врата смрти, прев. Миодраг Михајловић, Ниш.

Муди 2009: Рејмонд Муди, Живот после живота, Београд: Ленто.

Настасијевић 1991: Момчило Настасијевић, Сабрана дела III. Проза, Горњи Милановац - Београд: Дечје новине - Српска књижевна задруга.

Павловић 1990: Драгољуб Павловић, Има ли живота после смрти, Београд: ауторско издање.

Пантић 1990: Златимир Пантић, Како је Ђока Будић ишао на онај свет, Расковник, 61-62 (1990), 55-66.

Пантић 2005: Златимир Пантић. Тако је било, очију ми. Влашка магија и влашка чудеса, Велика Плана: Завет.

Петровић 1939: Александар Петровић, Грађа за изучавање наше народне религије. Гласник Етнографског музеја у Београду, XIV, 1939, 31-42.

Петровић 1984: Иван Петровић, На путу кроз пакао до раја, Ниш.

Повратак из онога живота. Чудесно виђење монахиње Евпраксије, Крњево: Православна народна хришћанска заједница, Црквена општина Крњево, 1978.

Поповић 2004: Јустин Поповић, Догматика Православне Цркве III, Ваљево: Задужбина Свети Јован Златоуст Аве Јустина Ћелијског и манастир Ћелије.

Роуз 1995: Серафим Роуз, Душа после смрти, Сремски Карловци: Српски Сион.

Стојановић 1997: Сретен Стојановић, Сећања на младост. 19041922, Београд: БИГЗ.

Тодоровић 1992: Тома Тодоровић, Србија пред вратима видовњака, Крагујевац: Нова светлост.

Цветковић 2000: Fra Bogdan Cvetković, Nebo. Vizije neba od proroka do ljudi naših dana, Zagreb: Sion.

\section{Архивска грађа}

Радојчић, Милош. Архивска грађа у Математичком институту САНУ.

\section{Интернет стране}

http://vidovitaseherzada.net/bs/o-meni-2; последњи пут приступљено 2.11.2020. 
https://www.telegraf.rs/vesti/srbija/3024362-zoran-sumadinac-tvrdi-daisceljuje-posle-3-klinicke-smrti-i-da-je-izlecio-sebi-tumor-emitujem-energijupreko-skajpa-i-vajbera-predvidjam-bolesti-video; последњи пут приступљено 2.11.2020.

http://www.manastir-lepavina.org/vijest.php?id=8595; последњи пут приступљено 2.11.2020.

\section{ЛИТЕРАТУРА}

Баева 2013: Вихра Баева, Раскази за чудеса. Локална традиция и личен опит, София: Академично издателство „Проф. Марин Дринов”.

Бошковић Стули 1975: Maja Bošković Stulli, Usmena književnost kao umjetnost riječi, Zagreb: Mladost.

Вигзел 2003: Faith Wigzell, The Ethical Values of Narodnoe Pravoslavie: Traditional Near-Death Experiences and Fedotov, Folklorica 8, 54-70.

Вигзел 2005: Faith Wigzell, Reading the Map of Heaven and Hell in Russian Popular Orthodoxy: Examining the Usefulness of the Concepts of Dvoeverie and Binary Oppositions, Forum for Anthropology and Culture 2, Санкт Петербург, 346-367.

Грицевская, Пигин 1993: И. М. Грицевская, А. В. Пигин, К изучению народных легенд об „обмирании”, Фольклористика Карелии, Петрозаводск: РАН, Карельский научный центр, Институт языка, литературы и истории, 48-68.

Делић 2015: Лидија Делић, Транссветовни идентитет и концептуализација оног света, Зборник Матище српске за књижевност и језик LXIII/1, 2015, Нови Сад, 59-70.

Детелић 1992: Мирјана Детелић, Митски простор и епика, Београд: Балканолошки институт САНУ.

Детелић 1996: Мирјана Детелић, Урок и невеста. Поетика епске формуле, Београд: Балканолошки институт САНУ.

Добровольская 1999: В. Е. Добровольская, Рассказы об обмираниях, Живая старина, 2, 1999, Москва, 23-25.

Ђорђевић Белић 2012: Смиљана Ђорђевић Белић, Методологија теренског истраживања фолклора: текстуализација усмене епике, у: Бошко Сувајџић (ур.), Српско усмено стваралаштво у интеркултурном коду, Београд: Институт за књижевност и уметност, 272-309.

Ђорђевић Белић 2015: Смиљана Ђорђевић Белић, Вукови принципи бележења епске грађе и савремени концепти фолклористичког терена, у: 
Нада Милошевић Ђорђевић (ур.), Вук Стефановић Караиић (1787-18642014), Београд: САНУ, 347-360.

Ђорђевић Белић 2019: Смиљана Ђорђевић Белић, Приче о сновима: проблеми, могућности и перспективе проучавања, у: Научни састанак слависта у Вукове дане, 48, Београд, 101-110.

Ђорђевић Белић 2020: Смиљана Ђорђевић Белић, Идејни комплекс 'веровати у снове' у светлу 'реторике истинитости'. Прилог проучавању жанра на примеру снова о мртвима”, Дејан Ајдачић, Бошко Сувајџић (ур.) Савремена српска фолклористика 8. Словенски фолклор и кьижевна фантастика, Београд: Удружење фолклориста Србије и др., 26-53.

Зечевић 1978: Слободан Зечевић, Самртни обичаји у околини Зајечара, Гласник Етнографског музеја, 42, Београд, 383-398.

Зечевић 1967: Слободан Зечевић, Самртни ритуал и неки облици култа мртвих у становништва влашког говорног језика Крајине и Кључа, Гласник Етнографског музеја, 30, Београд, 47-78.

Зечевић 1982: Слободан Зечевић, Култ мртвих код Срба, Београд, Вук Караџић - Етнографски музеј.

Јовановић 2009: Томислав Јовановић, Од апокрифа ка српској народној приповеци, Научни састанак слависта у Вукове дане, 38/2, Београд, $13-18$.

Криничная 2004: Н. А. Криничная, Русская мифология. Мир образов фольклора, Москва: Академический Проект, Гаудеамус.

Криничная 2005: Н.А. Криничная, Легенды о возвращении из загробного мира (по восточнославянским материалам), Этнографическое обозрение, 6, Москва, 114-129.

Криничная 2011: Н. А. Криничная, Легенды об „обмираниях”: предпосылки попадания на „тот свет”, Религиоведение 4, Благовещенск, 9-19.

Левкијевска 1997: Е. Е. Левкиевская, Москва в зеркале православных легенд, Лотмановский сборник 2, Москва: РГГУ. 805-835.

Ловел 2005: Stephen Lovell, Response to Faith Wigzell. Reading the Map of Heaven and Hell in Russian Popular Orthodoxy, Forum for Anthropology and Culture 2, Санкт Петербург, 368-373.

Лома 2002: Александар Лома, Пракосово. Словенски и индоевропски корени српске епике, Београд: Балканолошки институт САНУ.

Лурье, Тарабукина 1994: М. Л. Лурье; А. В. Тарабукина, Странствия души по тому свету в русских обмираниях, Живая старина, 2, 22-26.

Менцеј 2017: Mirjam Mencej, Styrian Witches in European Perspective: Ethnographic Fieldwork, London: Palgrave Macmillan. 
Милошевић Ђорђевић 1971: Нада Милошевић Ђорђевић, Заједничка тематско-сижејна основа српскохрватских неисторијских песама и прозне традииије, Београд: Филолошки факултет.

Никитина 2002: С. Е. Никитина, Сны и обмирания у духоборцев, у: О. Б. Христофорова (ред.), Сны и видения, Москва: РГГУ, 220-226.

Павићевић 2011: Александра Павићевић, Време (без) смрти. Представе о смрти у Србији 19-21. века, Београд: Етнографски институт CAHY.

Паунова 2002: Е. В. Паунова, Обмирания у липован, у: О. Б. Христофорова (ред.), Сны и видения, Москва: РГГУ, 181-197.

Пигин 1997: А. В. Пигин, Видения потустороннего мира в рукописной традиции XVIII-XIX вв, Труды Отдела древнерусской литератури 50, Санкт Петербург, 551-557.

Поповић Николић 2016: Данијела Поповић Николић, Други свет. Студије о демонолошким предағима и тужбалицама, Ниш: Филозофски факултет.

Радуловић 2003: Немања Радуловић, Симболични снови у усменој епици, Кюижевна историја, XXXV/119, 25-46.

Радуловић 2009: Немања Радуловић, Слика света у српским народним бајкама, Београд: Институт за књижевност и уметност.

Радуловић 2012: Немања Радуловић, Усуд у веровањима и приповеткама, у: Б. Сувајџић (ур.), Српско усмено стваралаштво у интеркултурном коду, Београд: Институт за књижевност и уметност, 311-402.

Радуловић 2020: Немања Радуловић, Подземни ток 2. Српска књижевност и езотеризам 1957-2000, Београд: Службени гласник.

Сафронов 2008: Е. В. Сафронов, Переход в инобытие: рассказы о иномирном опыте, Живая старина, 4 (60), 23-25.

Сафронов 2016: Е. В. Сафронов, Сновидения в традиционной культуре. Исследование и тексты, Москва: Лабиринт.

Самарџија 1997: Снежана Самарџија, Поетика усмених прозних облика, Београд: Народна књига, Алфа.

СМ 2001: Словенска митологија. Енциклопедијски речник, Београд: Zepter.

Сореску Маринковић 2009: Annemarie Sorescu Маринковић, Самовила код Влаха: интерпретација и реинтерпретација фолклорног текста, у: Моћ књижевности. In тетогіат Ана Радин. Београд: Балканолошки институт САНУ, 249-275. 
Станковић 2020: Ана Станковић, Наратолошки и имаголошки аспекти предања (докторска теза, Филолошко-уметнички факултет, Универзитет у Крагујевцу).

Тодорова Пиргова 1999: Ивета Тодорова Пиргова, Представления о „том свете” в биографических нарративах”. Живая старина, 2, 25-27.

Толстој 1995: Н. И. Толстой, О жанре обмирания (посещения того света). У: Язык и народная культура. Очерки по славянской мифологии и этнолингвистике, Москва: Индрик, 458-460.

Толстој 1999: С. М. Толстая, Полесские „обмирания”, Живая старина, 2, 22-23.

Толстој 2002: С. М. Толстая, Иномирное пространство сна, у: О. Б. Христофорова, Сны и видения, Москва: РГГУ, 198-218.

Толстој 2015: С. М. Толстая, Рассказы о посещении „того света” в славянской устной традиции в их отношении к книжному жанру „видении", у: Образ мира в тексте и ритуале. Москва: Университет Дмитрия Пожарского, 189-199.

Ћирковић 2009: Светлана Ћирковић, Стратегије у структурисању усменог наратива: загробни живот у религијском контексту, у: Моћ књижевности. In memoriam Ана Радин, Београд: Балканолошки институт CAHУ, 201-225.

Чередикова 2002: М. П. Чередикова, Письменая традиция обмираний, у: О. Б. Христофорова (ред.), Сны и видения, Москва: РГГУ, 227-246.

Nemanja J. Radulović

\section{FIRST PERSON AND THE OTHER WORLD}

\section{Summary}

The paper examines 30 texts (from interwar period to recent examples) unrecognized so far in Serbian folkloristics as belonging to the same corpus and representing a distinct genre. It is first-person narrative about the experience of temporary death and vision of the other world. This genre became first introduced in Russian folkloristics under the emic term obmiranie and since the pioneer work of N. and S. Tolstoi it became the topic of intensive research, especially in last 30 years. South Slavic examples, however, were only sporadically mentioned and most of them remained virtually unknown in this sense. The scheme of the genre, as discerned by Tolstois (introduction-circumstances of death; seeing the other world, travelling; returning to life) applies to Serbian narratives too, which confirms that we deal with a specific genre. While there is a couple of emic terms, etic term 
we propose is eschatological memorate. Motifs in these examples show the persistence of the traditional concepts of post-mortal existence, but at the same time they overlap with concepts stemming from Orthodox chap-books. The relation between written and oral tradition is therefore taken into account too as important for the transmission and for forming the wordview of the narratives. Finally, these narratives to some extent resemble NDE narratives, as popularized by R. Moody, but there is a strong difference since folk memorates retain traditional folk Christian worldview. However, we don't have examples of modern NDE, except for those from a couple of new age healers.

Key words: near-death experience, memorate, eshatology. 